Western Washington University Western CEDAR

$1-2009$

\title{
Indulging Our Gendered Selves? Sex Segregation by Field of Study in 44 Countries
}

Karen Bradley

Western Washington University, karen.bradley@wwu.edu

Maria Charles

Follow this and additional works at: https://cedar.wwu.edu/sociology_facpubs

Part of the Sociology Commons

\section{Recommended Citation}

Bradley, Karen and Charles, Maria, "Indulging Our Gendered Selves? Sex Segregation by Field of Study in 44 Countries" (2009). Sociology. 2.

https://cedar.wwu.edu/sociology_facpubs/2 


\section{CHICAGO JOURNALS}

Indulging Our Gendered Selves? Sex Segregation by Field of Study in 44 Countries Author(s): Maria Charles and Karen Bradley

Source: American Journal of Sociology, Vol. 114, No. 4 (January 2009), pp. 924-976

Published by: The University of Chicago Press

Stable URL: http://www.jstor.org/stable/10.1086/595942

Accessed: $27 / 10 / 2014$ 16:37

Your use of the JSTOR archive indicates your acceptance of the Terms \& Conditions of Use, available at http://www.jstor.org/page/info/about/policies/terms.jsp

JSTOR is a not-for-profit service that helps scholars, researchers, and students discover, use, and build upon a wide range of content in a trusted digital archive. We use information technology and tools to increase productivity and facilitate new forms of scholarship. For more information about JSTOR, please contact support@ jstor.org. 


\title{
Indulging Our Gendered Selves? Sex Segregation by Field of Study in 44 Countries $^{1}$
}

\author{
Maria Charles \\ University of California, Santa Barbara \\ Karen Bradley \\ Western Washington University
}

Data from 44 societies are used to explore sex segregation by field of study. Contrary to accounts linking socioeconomic modernization to a "degendering" of public-sphere institutions, sex typing of curricular fields is stronger in more economically developed contexts. The authors argue that two cultural forces combine in advanced industrial societies to create a new sort of sex segregation regime. The first is gender-essentialist ideology, which has proven to be extremely resilient even in the most liberal-egalitarian of contexts; the second is self-expressive value systems, which create opportunities and incentives for the expression of "gendered selves." Multivariate analyses suggest that structural features of postindustrial labor markets and modern educational systems support the cultivation, realization, and display of gender-specific curricular affinities.

In a dramatic reversal of fortune, women have recently gained majority status among new college and university graduates in the United States and most other industrial countries (Schofer and Meyer 2005; Buchmann

\begin{abstract}
${ }^{1}$ This research was supported by grants from the National Science Foundation (NSF HRD-0332852 and NSF SBR-9808038), the Spencer Foundation, and the American Educational Research Association. Opinions are those of the authors and not necessarily of the granting agencies. Erin Cech, Colin Ong-Dean, and Mayumi Uno provided valuable research assistance and comments. Earlier versions were presented at Cornell, Harvard, Northwestern, UC San Diego, UC Santa Barbara, Stanford, Western Washington, and Yale. We are grateful to colleagues at these institutions and to the AJS reviewers for helpful feedback and advice. The first author wishes in particular to acknowledge contributions by friends and former colleagues at UCSD. Direct correspondence to Maria Charles, Department of Sociology, University of California, Santa Barbara, California 93106-9430. E-mail: mcharles@soc.ucsb.edu
\end{abstract}

(C) 2009 by The University of Chicago. All rights reserved. 0002-9602/2009/11404-0002\$10.00 
and DiPrete 2006; Shavit, Arum, and Gamoran 2007). While it is widely recognized that institutions of higher education remain internally sex segregated, scholars and policy makers frequently represent women's impressive enrollment gains as a first step toward the gradual elimination of gender differentiation within the public sphere. By these accounts, sex segregation is a traditional relict that will decline under modern competitive pressures, or as egalitarian values are institutionalized and become manifest in attitudes and career aspirations (Jackson 1998, 2006; National Agency for Higher Education and Statistics Sweden 1998; Inglehart and Norris 2003; Baker and Letendre 2005).

Much evidence can be found to support such evolutionary arguments. The second half of the 20th century has witnessed important and farreaching improvements in many aspects of women's status. Women have gained formal legal and political rights in most countries, female participation in many key institutions has soared, and public support for overtly discriminatory policies and practices has declined markedly (Ramirez, Soysal, and Shanahan 1997; England 2006; Jackson 2006). But, with respect to the segregation of educational systems and labor markets, accounts positing an erosion of gender differentiation ("degendering") have received little empirical support. U.S. studies point to persistently high levels of segregation in colleges and universities, with women strongly underrepresented in science, engineering, and technical programs even in countries with high overall female enrollment rates (Jacobs 2003; Xie and Shauman 2003; England and Li 2006; England et al. 2007). Recent comparative analyses suggest, moreover, that some forms of segregation are more, not less, pronounced in the most socially or culturally modern societies (Bradley 2000; Charles and Bradley 2002, 2006; Charles and Grusky 2004; Van Langen and Dekkers 2005).

We argue that conventional evolutionary models of women's status cannot provide a satisfactory account of cross-national and historical variability in sex segregation by field of study because they underestimate the enduring cultural force of gender-essentialist ideology (i.e., cultural beliefs in fundamental and innate gender differences), which has proven to be extremely influential in shaping life experiences, expectations, and aspirations, even in the most liberal egalitarian societies (Fenstermaker and West 2002; Charles and Grusky 2004; Correll 2004; Ridgeway 2006). The segregative effect of gender-essentialist beliefs is intensified, moreover, by a strong Western cultural emphasis on individual self-expression and self-realization that has been diffusing worldwide since World War II (Meyer and Jepperson 2000; Frank and Meyer 2007) and is today most clearly evident in affluent late-modern societies (Inglehart 1997; Beck and Beck-Gernsheim 2001). Because gender remains so central an axis of human identity, we argue that self-expressive value systems tend to en- 
courage the development and enactment of culturally masculine or feminine affinities. Girls may, for example, be more likely to express an aversion to mathematics and avoid related programs where self-expression is a legitimate, and even normative, criterion for curricular choice.

Structural features of modern educational systems and labor markets may also promote gender-differentiated aspirations and their realization. Today's highly diversified tertiary curricula were designed to maximize possibilities for students to exercise expressive choices and to accommodate the presumed interests of newly incorporated female students (Bradley and Charles 2004; Frank and Meyer 2007). Postindustrial economies, with their abundance of female-labeled service jobs, are, likewise, potentially segregative forces. The proliferation of gendered educational and occupational pathways encourages sex typing of career expectations and dispositions, even as overt discrimination and exclusionary practices are delegitimated. Powerful self-fulfilling prophesies thus operate in the gender labeling of occupations, educational fields, and persons.

The current study uses international data and log-linear methodology to model cross-national variability in sex segregation by field of study as a function of cultural gender beliefs (i.e., gender gaps in reported affinity toward mathematics) and macrolevel features of educational systems, economies, and labor markets. Our sample comprises 44 industrial, transitional, and developing countries and territories that exhibit considerable variability with respect to the predictors of interest. This diverse sample sets our study apart from previous analyses, which have explored relationships primarily for advanced industrial societies. ${ }^{2}$

In the following sections we elaborate our arguments regarding the cultural and structural forces shaping cross-national variability in sex segregation by field of study. We then introduce our data and describe men's and women's relative distributions across fields in 44 countries and territories. Contrary to the predictions of many evolutionary theorists, we find a general tendency for greater segregation of academic fields in more economically developed contexts. But our multivariate analyses reveal important discontinuities between developing/transitional and advanced industrial societies in the processes generating this form of gender inequality, suggesting that distinct sex segregation regimes may indeed operate in "materialist" and "postmaterialist" societies. Theoretical and empirical implications are discussed in the concluding section.

\footnotetext{
${ }^{2}$ One might well argue that previous analyses did not constitute fair empirical tests of evolutionary accounts, since economic development effects were considered only over a restricted range.
} 
Sex Segregation

\section{CULTURE, STRUCTURE, AND THE GENERATION OF SEX SEGREGATION}

The above discussion points to three macrosocietal forces that may work against a degendering of modern educational institutions: (1) cultural value systems that celebrate gender difference and simultaneously endorse self-expression (including gendered self-expression) as an educational goal, (2) expansion and structural diversification of higher education systems and the resultant consolidation of gender-specific curricular niches, and (3) postindustrialism and the growth of "female-demanding" occupational sectors. These potentially segregative effects are discussed in successive sections below. Although "modern" structural and cultural forms are correlated with economic development (e.g., high GDP), they emerge through both local and transnational processes, and each is likely to exert distinctive effects on sex segregation. We therefore treat economic prosperity, cultural value systems, educational structures, and postindustrial labor markets as independent causal factors. Where relevant, we consider how covariate effects may vary across country groups (advanced industrial vs. developing/transitional).

\section{Gender, Self-Expression, and Curricular Choice}

Among the many classificatory systems that shape social relations and identities in the contemporary world, sex category consistently emerges as the "most automatic, pervasive and earliest learned" (Glick and Fiske 1999, p. 368). The cultural centrality of sex typing is relevant to the question at hand because sex categorization automatically activates stereotypes and gendered expectations of self and others, which have shown remarkable historical resilience (Banaji and Hardin 1996; Correll, Benard, and Paik 2007). In fact, a recent review of some 30 previous studies finds no evidence of decline in gender-essentialist stereotypes in the United States between 1974 and 1997 (Lueptow, Garovich-Szabo, and Lueptow 2001). Modern individuals are deeply invested in beliefs about gender difference, and these are embedded in virtually all organizational structures and interactional contexts, including families, labor markets, and educational systems. In Ridgeway's (2006) terms, gender serves as "a primary framing device for social relations," even in societies where egalitarian principles are widely endorsed (see also Bem 1993).

Previous microlevel research suggests that both persons and the social roles that they inhabit (e.g., educational and occupational positions) are widely perceived to be intrinsically masculine or feminine and that these beliefs result in gender-differentiated dispositions and expectations. Girls and women are more likely to express preferences for work that is reputed 
to require female-labeled skills, while their male counterparts express preferences for work reputed to require male-labeled skills (Stenstrom 1993; Marini et al. 1996; Seymour and Hewitt 1997; Bae et al. 2000; Eccles 2007). We use the term preference in its broadest sense here, to encompass values socialized and internalized at the individual level, as well as the performative enactment of cultural scripts. ${ }^{3}$ Both dispositional processes are likely to result in a great deal of sex segregation across fields of study, even within universities that follow formally egalitarian allocational procedures.

The content of gender-essentialist stereotypes shows much consistency across time and space, with women viewed as naturally better at nurturance and interpersonal relations and men viewed as stronger, more analytical, and more skilled in interaction with things (Williams and Best 1990; Lueptow, Garovich-Szabo, and Lueptow 2001). But historical and comparative case studies also reveal significant fluidity. For example, different versions of masculinity (emphasizing muscularity or abstract logic) have been more or less salient in different fields, depending in part upon the demographic and social pressures operative at the time of each field's development or expansion (Bielby and Baron 1984; Cockburn 1985; Milkman 1987; Faulkner 2000). ${ }^{4}$ Such observations lead us to expect baseline similarities in the sex typing of curricular fields, but with significant deviations that reflect local circumstances and national histories. Case-bycase discussion of such deviations is not possible in the present context. Our goal is rather to identify general patterns in the data in order to discern some common tendencies.

A central tenet of our theoretical argument is that gender-essentialist stereotypes and dispositions combine with norms of self-expression to intensify gender typing of curricular choice in societies characterized by broad-based prosperity and material security (i.e., in advanced industrial societies). Scholars based in diverse intellectual traditions have pointed to an increased valuation of individual self-expression, choice, and quality of life in the (post)modern world (Giddens 1990; Inglehart 1997; Meyer

\footnotetext{
${ }^{3}$ Social scientists have treated gender-differentiated educational and career aspirations as hardwired (Baron-Cohen 2003), as deeply internalized (e.g., Chodorow 1978), as reflections of opportunity structures (Kanter 1977), and as enactments of diffuse cultural schemas that label tasks as either "feminine" or "masculine" (Correll 2001; Fenstermaker and West 2002; Nosek, Banaji, and Greenwald 2002).

${ }^{4}$ Gender-essentialist beliefs are generally not undermined by shifts in occupational gender labeling, because a mixture of "masculine" and "feminine" skills can be found in most activities. It is not difficult, for example, to identify service components in scientific or technical work or analytical components in traditionally female service work.
} 
and Jepperson 2000; Inglehart and Welzel 2005; Frank and Meyer 2007). ${ }^{5}$ Inglehart (1997) has linked this shift to widespread existential security, which helps legitimize self-realization and "quality of life" as educational and career goals and creates opportunities for persons to disregard economic costs associated with indulging individual educational and career preferences. ${ }^{6}$ One well-documented economic cost associated with femaletyped curricular choices is the foreclosure of generally more lucrative technical and scientific careers in favor of personal service and administrative work.

Normative mandates for self-expression and the associated celebration of individual choice encourage sex segregation because males and females draw upon different cultural schemas and different social resources as they seek to realize and express their true "selves," and because they anticipate that others will hold them accountable to established gender scripts (Fenstermaker and West 2002; Correll 2004; Ridgeway and Correll 2004). Pursuit of gender-conforming fields and occupations is, among other things, a way for individuals to affirm their essential femininity or masculinity (Xie and Shauman 2003; Ridgeway 2006; Faulkner 2007). While universalistic principles and ideals of self-expression can provide normative space for some women and men to transgress conventional gender norms, the widespread taken-for-grantedness of essentialist beliefs and the centrality of gender as an axis of individual identity imply a preponderance of gender-typical choices. Beliefs about gender difference can thus spawn powerful self-fulfilling prophesies.

Although we are not challenging Inglehart's empirical findings that show a positive effect of self-expressive values on "gender empowerment" (Inglehart and Welzel 2005), we do take issue with his unidimensional conceptualization of women's status and his atomized depiction of individual choice. In contrast to the "rising tide" analogy deployed by Inglehart and others, we advance a multidimensional view of women's status

\footnotetext{
${ }^{5}$ Neoinstitutionalists also emphasize the worldwide diffusion of self-expressive values through global institutions and interdependencies (e.g., Meyer and Jepperson 2000; Frank and Meyer 2007). We do not have the data necessary to assess the relative importance of global and local sources of self-expressive value systems. While these values may be increasingly prevalent worldwide, our arguments are based on the presumption that they are stronger and more widely held in advanced industrial societies (Inglehart 1997; Inglehart and Welzel 2005).

${ }^{6}$ Of course, not all persons in advanced industrial countries can afford to disregard the material consequences of life choices; the extent to which citizens pursue quality of life over material security varies a great deal within societies. But the postmaterialism thesis suggests macrolevel cultural effects: once some critical mass of the population experiences material security, cultural shifts should follow. The resultant self-expressive values are presumed to influence the curricular choices of even those persons with good reason to be concerned about their material security.
} 
whereby different indicators-for example, university access and integration of curricular fields-may rise and fall according to distinct causal logics. Inglehart's gender empowerment index is strongly influenced by variability in "vertical" forms of sex segregation (i.e., female exclusion from high-status social roles), which have indeed eroded with the rise of liberal egalitarian and self-expressive values. Our argument applies specifically to those "horizontal" forms that are widely understood to result from free choices by persons with intrinsic preferences for male- or femalelabeled activities. ${ }^{7}$ Sex segregation by field of study derives its legitimacy not from norms of male primacy, but from its seeming homology with gender-essentialist beliefs and dispositions. It is therefore less politically and socially contested than are many types of vertical inequality, and it is easily reconciled with self-expressive value systems. In fact, this type of sex segregation may not even constitute "inequality" in Inglehart's strict sense. $^{8}$

In short, we argue that evolutionary scholars are overly optimistic about prospects for an across-the-board degendering of educational institutions because they underestimate the enduring cultural force of gender-essentialist ideology in shaping individual life experiences, dispositions, and identities and in labeling academic fields as intrinsically masculine or feminine. The mass emphasis on self-expressive values and the dazzling array of gender-typed curricular and career options characteristic of advanced industrial societies increase opportunities (and expectations) for persons to develop, realize, and express sex-typed educational and career aspirations. The increased segregation of educational fields (and labor markets) that is generated through these processes may in turn strengthen gender-essentialist stereotypes and influence the educational expectations and aspirations of subsequent student cohorts in the direction of greater sex typing. In other words, individual self-expression may imply construction and expression of "gendered selves."

The above discussion implies (1) a general tendency for men's and women's distributions across fields of study to correspond to gender differences in curricular affinities, (2) a stronger link between curricular affinities and curricular distributions in advanced industrial societies than

\footnotetext{
${ }^{7}$ On the distinct cultural principles sustaining vertical and horizontal sex segregation, and on their differential responsiveness to liberal egalitarian cultural ideals, see Charles and Bradley (2002) and Charles and Grusky (2004). Horizontal segregation refers to distributional inequalities that are not explicitly hierarchical, while vertical segregation refers to inequalities in rank or prestige. The latter is not formally considered here.

${ }^{8}$ Inglehart and Welzel (2005, p. 284) define equality as "the degree to which women have equal opportunity to develop their potential for autonomous choice." By this definition, which is culturally dominant in advanced industrial societies, preferences are conceptualized as residing in atomized individuals.
} 
in developing/transitional societies, and (3) a larger gender gap in curricular affinities in advanced industrial societies. We examine these relationships using aggregate-level data on girls' and boys' expressed affinities for mathematics in 44 countries and territories. The first two relationships are assessed on the basis of multivariate log-linear models, first for the sample as a whole, and then by country group (advanced industrial vs. developing/transitional). We do not formally model determinants of crossnational variability in gender-differentiated curricular affinities (item 3 above), but we are able to gain some sense of these cultural differences by comparing mean male-female affinity gaps between advanced industrial and developing/transitional societies.

\section{Expansion, Feminization, and Diversification of Higher Education}

The 20th century saw a massive expansion and democratization of higher education worldwide. The first to benefit were men in the industrialized West, but women and citizens of most independent developing countries followed within a decade or two of the Second World War. At the international level, these trends were supported by a changing model of higher education. Rather than emphasizing elite training functions, economists and educational policy makers advocated broad-based and generalized human capital investment as means for advancing national prosperity and social efficiency (Schultz 1961; Meyer et al. 1977; Schofer and Meyer 2005). International organizations such as UNESCO, the World Bank, and the Organisation for Economic Development (OECD) worked with governments, especially in less economically developed countries, to promote universalistic ideals-including gender parity in enrollments-at all educational levels (Bradley and Ramirez 1996; Berkovitch and Bradley 1999; Ramirez and Wotipka 2001).

Although educational expansion has occurred virtually everywhere since the 1960s, countries continue to exhibit much variability with regard to the size and organization of their systems of higher education. In the following paragraphs, we consider how three structural features of educational systems-size, structural diversification, and level of female participation-may influence patterns of sex segregation across fields of study. In general, we suggest that modernization of higher education (i.e., enrollment expansion, structural diversification, and gender parity in enrollments) is associated with proliferation of curricular programs and an increasing tendency for gender stereotypes to be enacted, normalized, and reinforced within systems of higher education.

System size.-Larger systems incorporate a broader cross-section of the population. As a result, proportionately fewer members of the student body regard themselves as part of an academic elite. Where systems of 
higher education are small and selective, academic prowess or social class can trump other distinctions. Gender is likely to become increasingly salient to curricular choice as the university population grows because a smaller share of students will possess the elite identity and sense of selfefficacy required for transgressing cultural gender norms (see Della Fave [1980] and Gecas [1991] on the relationship between elite status and selfefficacy). This argument suggests a tendency for larger systems to be more internally sex-segregated.

Diversification.-Expansion of higher education was partly accomplished through internal differentiation, a signifier of educational democratization and modernization that occurred first in the most affluent industrial countries and later in the developing world (Sirowy and Benavot 1986; Kerr 1991; Meek and Goedegebuure 1996; Frank and Meyer 2007). Structural diversification has broad appeal among educational policy makers and the public, in part because it enhances opportunities for students to exercise expressive choices. It has also been motivated historically by efforts to create feminine enclaves within higher education. The infusion of gender-essentialist ideology into educational policy making is evident in the UNESCO recommendation, directed toward national ministries of education,

that to facilitate women's access to higher education and the use of their abilities for the greatest good of society, university studies permit women to specialize in fields particularly suited to feminine aptitudes and assure them more adequate training for the new careers now being opened up to them. (UNESCO 1953, p. 263)

"Feminine aptitudes" and women's career opportunities have been accommodated through development of new four-year degree programs (e.g., physical education, human development, teacher education, law), through establishment and expansion of vocational and two-year degree programs (e.g., health care, secretarial and library studies, business administration, tourism/hospitality), and through reclassification of strongly gender-typed vocational programs (e.g., nursing, early childhood education) from the secondary or interstitial level to the tertiary level of the educational system (Elgqvist-Saltzman 1988; Fjelde 1991; Teichler 1996; Rossiter 1997; Bix 2006). Modes of female incorporation have thus been influenced by prevailing understandings of natural and appropriate feminine roles.

Based on data from advanced industrial countries, past research has linked one type of structural diversification-expansion of two-year and vocational colleges - to increased sex segregation by field of study (Charles and Bradley 2002; Rawlings 2007). The widespread availability of twoyear programs in such fields as early childhood education, library studies, 
business administration, service trades, and medical technology appears to result in the diversion of some university-qualified women into strongly sex-typed vocational degree programs. We examine the generalizability of this previously documented relationship to less economically developed contexts. Although the original formulations of this argument imply crossnationally uniform effects of diversification on sex segregation, the theoretical account advanced above suggests that segregative effects will be stronger in postmaterialist societies: where gendered self-expression is normatively sanctioned and widely expected, structural opportunities for gender-differentiated curricular choice should produce more sex segregation.

Female enrollment rates.-All else equal, female representation in traditionally male-typed fields of study is likely to be weaker in systems where women make up a larger proportion of higher education students. First, initiatives to increase female enrollments may prompt educators and administrators to intensify efforts to accommodate women as a group (e.g., by developing "female-friendly" curricula and institution types). Second, proportionately fewer female students are likely to regard themselves as "exceptional women" and as "pioneers" in systems where female enrollment is taken for granted (for similar culling arguments, see Hakim 1991; Charles and Grusky 2004). These two processes likely work in opposition to the empowering and integrative effects of large-scale female incorporation described by neoinstitutionalist scholars (Ramirez and Wotipka 2001; Baker and Letendre 2005).

Postindustrialism, the Labor Market, and the Economy

Postindustrialism refers to global trends away from manufacturing and toward rationalized, service-based economies. This economic transformation coincides with shifts in social consciousness whereby social life and institutions are increasingly influenced by a pervasive means-ends rationality, a growing emphasis on meritocratic allocational criteria, and an expansion of the self in terms of needs, wants, and interests (Bell 1976; Meyer and Jepperson 2000). It is well established that postindustrialism is associated with restructuring and massive growth of female-labeled service occupations (Oppenheimer 1970; Charles and Grusky 2004; England 2005). Both rational-choice and cultural arguments suggest a tendency for increased sex segregation by field of study as these structural developments unfold. From a rational-choice perspective, women will be cognizant of growing service-sector opportunities (in particular, the high demand for female labor in these fields) and will adjust their curricular choices accordingly, for example, by investing in social science, business, education, human development, or health degrees (Estévez-Abe, Iversen, and Soskice 2003). From a cultural perspective, the proliferation of female- 
dominated service jobs and their elevation to semiprofessional status validates these as rational and meaningful outlets for the talents of collegeeducated women, independent of any actual utility-maximizing calculations (Baker and Jones 1993; Frank and Meyer 2007). While countries certainly differ in the extent to which educational and occupational fields are gender labeled, we presume a significant baseline level of cultural gender labeling in all countries considered here. ${ }^{9}$

It is often suggested that gender equality in the labor market-in particular, large-scale participation of women in the labor force and in professional occupations-will promote integration of educational programs. Neoclassical economic and other rational-choice accounts of educational investment hold, for example, that girls and women will more often seek training in male-dominated fields in contexts where they have reason to expect continuous employment and where they perceive more opportunities for women in high-status occupations (e.g., Polachek 1978; see also Estévez-Abe et al. 2003). And neoinstitutionalist accounts suggest that integrative "spillover" effects will follow from increased female labor force participation, as women come to understand themselves as equal citizens entitled to the same rights and opportunities as their male counterparts (Ramirez 1987; Baker and Jones 1993). By both accounts, sex segregation by field of study should be negatively related to women's overall labor force participation rates and to women's representation in high-status occupations. Although past research provides no evidence linking labor market opportunities for women to desegregation of educational fields (e.g., Charles and Bradley 2002), these relationships have not yet been explored for less-developed and transitional countries.

To evaluate the descriptive validity of evolutionary claims positing declines in gender differentiation with socioeconomic modernization (Goode 1963; Parsons 1970; Jackson 1998, 2006; Inglehart and Norris 2003), we also examine - through bivariate and multivariate analysesthe relationship of sex segregation to countries' overall level of economic development. We examine this effect for the full sample and separately for advanced industrial and developing/transitional societies. Our results show a clear positive relationship of GDP to sex segregation for developing/transitional societies only. The segregative effects of economic prosperity within this country group may be attributable to weakening material constraints on women's educational choices. This effect is detectable only up to a point, however. Among advanced industrial societies, further increases in national prosperity (GDP) do not exert segregative pressures on curricular distributions because existential security is now widely taken

${ }^{9}$ We present empirical support for this presumption below. 
for granted. We argue that expression of gendered selves is more legitimate, and perhaps even expected, in these contexts.

Based on the arguments advanced above, we examine for 44 countries and territories the overall effects on sex segregation of nine macrolevel covariates. In addition, we explore the potentially interactive effects of self-expressive value systems by comparing patterns of covariate effects between advanced industrial (postmaterialist) and developing/transitional (materialist) societies. As discussed above, we are particularly interested in how the effects of gendered curricular affinities, economic development (GDP), and tertiary diversification vary between these country groups.

\section{DATA AND METHODS}

Forty-four developed, developing, and transitional societies are included in our sample, based on availability of the requisite data. We selected all countries and territories (1) that participated in the 1995 or 1999 Trends in International Math and Science Surveys (TIMSS) and (2) for which published information on gender distributions across fields of study was available from the United Nations Educational, Scientific and Cultural Organization (UNESCO). ${ }^{10}$ Data are taken for the most recent available year, generally in the mid-1990s. Although very low-income countries are underrepresented, the countries considered are quite diverse with respect to most variables considered here.

\section{Sex Segregation Data}

Using absolute counts submitted by national governments to UNESCO, we assembled a three-way data table cross-classifying higher education graduates by sex, field, and country. Counts are aggregated across the three levels of higher education identified by UNESCO (i.e., vocational, university, and postgraduate). ${ }^{11}$ Given large differences across countries and fields in student attrition rates, we restrict our analysis to graduates. This means that observed patterns of sex segregation reflect gender differences in both initial choices of major and persistence within those majors.

To increase the international comparability of programmatic categories and to eliminate empty cells, we collapsed the categories of UNESCO's international standard classification of education (ISCED) into the fol-

${ }^{10}$ TIMSS is coordinated by the International Study Center at Boston College and is funded by national governments, the World Bank, and the United Nations Development Fund.

${ }^{11}$ Cross-classification of field by level was not possible because of missing data. 
lowing four fields: engineering, mathematics and natural sciences, humanities and social sciences, and health/other (a composite of the remaining fields, with the plurality of graduates completing degrees in health-related subfields). ${ }^{12}$ While three of these four categories are quite heterogeneous, disaggregated data on engineering graduates were available in all countries, making this the most cross-nationally comparable and internally homogeneous category. ${ }^{13}$ These data therefore allow us particular specificity in identifying the factors affecting female representation in this highly rewarded and strongly male-dominated field. More information on data sources and our classification of fields can be found in appendix A.

\section{Models and Measurement}

We examine the descriptive contours of segregation by calculating fieldspecific sex segregation parameters for each country. These terms $\left(A_{j}\right)$ contrast the (female-to-male) ratio in the respective field to that in the "average" field of study. They can be expressed as

$$
A_{j}=\ln \left(F_{j} / M_{j}\right)-\left[1 / J \times \Sigma \ln \left(F_{j} / M_{j}\right)\right],
$$

where $F_{j}$ and $M_{j}$ are the numbers of women and men graduates, respectively, in field $j$, and $J$ is the number of fields. Negative values indicate female underrepresentation, and positive values indicate female overrepresentation relative to the other fields of study. Values closer to zero are indicative of greater gender integration. Exponents of these segregation terms (not presented) give the multiplicative factor by which women are over- or underrepresented in the respective field and country. Field-specific values can be combined into a summary index, $A$, which gives, for each country, the multiplicative factor by which women or men are overrepresented in the average field. ${ }^{14}$ Although we present values of $A$, our primary focus is on the field-specific terms, because countries differ not only in overall levels but also in their qualitative (i.e., field-specific) patterns of sex segregation. The results of our multivariate analyses reveal, moreover, that many covariates affect segregation in field-specific rather than across-the-board fashion.

\footnotetext{
${ }^{12}$ Although students in health-related programs (e.g., nursing, medical, dental) may complete significant coursework in the life sciences, these curricula and degrees are generally more applied than those listed under the natural science rubric.

${ }^{13}$ In fact, many countries are today converging on a common (American-influenced) engineering curriculum, which blends theoretical with applied knowledge. Engineering programs in Colombia, for instance, have been approved by the U.S. Accreditation Board for Engineering and Technology (ABET).

${ }^{14}$ The formula for $A$ is given below (see also Charles and Grusky 1995, 2004).
} 
The $A_{j}$ terms, represented in closed form above, are essentially threeway (sex $\times$ field $\times$ country) interaction terms from a saturated log-linear model $\left(\delta_{i j k}\right.$ in eq. [2] below). Because they are functions of odds ratios, these measures have the important virtue of being invariant to crossnational differences in both the gender composition of the national student body and the relative sizes of educational fields. This "margin-invariance" facilitates cross-national comparison and promotes better understanding of the causal mechanisms underlying sex segregation. ${ }^{15}$

The macrolevel predictors of sex segregation by field of study are explored through a series of log-linear models. These take the general form

$$
m_{i j k}=\alpha_{k} \beta_{i k} \gamma_{j k} \delta_{i j k},
$$

where $i$ indexes sex, $j$ indexes field, $k$ indexes country, $m_{i j k}$ is the expected frequency in cell $i j k, \alpha_{k}$ is the grand mean for the $k$ th country, $\beta_{i k}$ accounts for cross-national differences in overall female enrollment rates (i.e., the marginal effect of sex), and $\gamma_{j k}$ accounts for cross-national differences in the relative sizes of educational fields (i.e., the marginal effect of field). Rather than allowing the sex segregation parameters $\left(\delta_{i j k}\right)$ to vary freely by country, our model constrains them to be linear functions of countrylevel covariates, as follows:

$$
\delta_{i j k}=a_{j}+\boldsymbol{b}_{j} \boldsymbol{X} .
$$

In equation (3), $a_{j}$ is the intercept for the $j$ th field, and $\boldsymbol{b}_{j} \boldsymbol{X}$ is a vector of country-level covariates and their slopes. The slope coefficients $\left(\boldsymbol{b}_{j}\right)$ specify the strength and direction of the relationship between the covariate and our field-specific sex segregation terms. ${ }^{16}$ Essentially, then, women's representation in educational fields $\left(A_{j}\right)$ constitutes the dependent variable of these multivariate models. To identify the models, the $\delta_{i j k}$ terms are constrained to sum to zero within each country. Equations are estimated using a maximum-likelihood procedure.

\footnotetext{
${ }^{15}$ For example, it is not possible to assess the effects of increasing female enrollments on sex segregation when variability in enrollment rates is conflated with distributional inequality. The deficiencies of compositionally dependent measures have not gone unnoticed, and scholars have devoted much effort to standardizing conventional indices (e.g., $D$ ). However, the only truly compositionally invariant measures are based on odds ratios (Charles and Grusky 1995, 2004). See also Rudas (1998) on the properties of odds ratios.

${ }^{16}$ Without the covariate constraints on the sex segregation parameters, the model shown in eq. (2) would be saturated, and the $\delta_{i j k}$ terms would be equivalent to $A_{j}$ (eq. [1]). This modeling framework is based upon Xie's (1992) log-multiplicative layer-effects model. Previous applications of this log-multiplicative approach to the study of sex segregation can be found in Charles and Grusky (2004, chap. 4), Charles (1992, 2005), and Charles and Bradley (2002).
} 
We assess the fit of nested models using the likelihood-ratio chi-squared statistic $\left(L^{2}\right)$, which indicates how well a given model reproduces observed cell counts. The power of specific covariates to account for international differences in the structure of sex segregation can be evaluated with regard to explained variation, defined as the percentage difference in $L^{2}$ between the baseline model and the respective explanatory model. ${ }^{17}$ To identify more parsimonious "preferred" models, we base covariate selection on a $5 \%$ deletion criterion, meaning that covariates are deleted sequentially until none can be eliminated without reducing explained variation by $5 \%$ or more. In supplementary models (not shown), we apply a more liberal $3 \%$ standard for covariate deletion, with very similar results. Discrepancies between models utilizing $3 \%$ and $5 \%$ deletion standards are noted.

\section{Covariates}

Here, we provide information on our measurement of country-level covariates (more details on sources are provided in app. A; individual country scores are listed in app. table B2). The arguments advanced above suggest that gender-differentiated affinities influence curricular choices, and that these effects will be stronger in affluent postindustrial societies. While we do not have the data to measure the effects of gendered dispositions on programmatic choice directly (i.e., at the individual level), we are able to assess the extent to which patterns of cross-national variability in sex segregation correspond to aggregate-level gender differences in one sort of curricular taste: affinity for math. These data, taken from the 1995 and 1999 waves of TIMMS, are based on boys' and girls' responses to the question "Do you like math?" aggregated within each country or territory. We compare girls' and boys' reported affinities based on information collected from students enrolled in the equivalent of the U.S. eighth grade. This stage in the educational career is especially consequential, as students are making curricular decisions either to begin the highly sequenced progression of mathematics and science courses or to pursue options that may preclude advanced study in these areas. Past research shows divergence of boys' and girls' attitudes toward mathematics and science at around the eighth or ninth grade (Catsambis 1994; Hanson 1996). Such divergence is at least partly attributable to girls' and boys' reactions to and enactment of cultural gender schemas; we therefore treat this aggregate-level variable as an indicator of the extent to which mathematics and mathematics curricula are culturally gendered.

${ }^{17}$ Relative, not absolute, criteria guide model selection. Given our sample size of nearly 9 million graduates, only the saturated model yields negative BIC statistics or statistically nonsignificant chi-squared values. 
Our models also include a control variable, taken from the TIMMS database, that measures the country-level gender gap in eighth-grade math achievement scores. We thus account for any aggregate-level correlation of affinities with achievement.

We also explore effects of educational structure, taking the relevant information from UNESCO publications (see app. A for details). Tertiary system size is measured as the natural log of total student enrollment, ${ }^{18}$ educational diversification is measured as the share of higher education students enrolled in nonuniversity (i.e., vocational and/or two-year degree) programs, and female participation is measured as women's share of all higher education graduates (graduates \% female).

A third cluster of variables relates to characteristics of the economy and the labor force. We measure postindustrialism using a composite index. Its value gives the mean of standardized values on two variables: the share of the labor force working as employees (as opposed to ownaccount workers) and the share of the labor force working in service industries (see also Charles 1992; Charles and Grusky 2004). Female labor force participation is measured as women's share of the labor force (labor force \%female), and female opportunities for high-status employment are measured as women's share of professional workers (professions \%female). To allow for lagged effects on curricular choice, we use values for 1990, approximately five years prior to graduation. Labor force data are taken from databases assembled by the International Labour Organization (ILO) and the United Nations.

As a rough proxy for the influence of postmaterialist, self-expressive values, we distinguish between advanced industrial and developing/transitional societies and explore covariate effects separately for each group. We define as advanced industrial those states that are prosperous (i.e., that have a high GDP) and were members of the OECD at least 20 years prior to the collection of our educational data (i.e., by 1974). We do not divide our sample solely on the basis of national income because theoretical arguments about the rise and mass-societal diffusion of selfexpressive values require prosperity that is long-standing and broad-based enough to support a culture of existential security. All countries in the advanced industrial group have per capita GDPs exceeding the sample median $(\$ 7,723)$, and they correspond closely to those identified as "postindustrial older democracies" by Inglehart and Norris (2003, app. table A1). ${ }^{19}$

${ }^{18}$ We also examined effects of per capita enrollment rates with similar results.

${ }^{19}$ Australia, Austria, Belgium, Canada, Denmark, Finland, France, Germany, Ireland, Italy, Japan, the Netherlands, New Zealand, Norway, Spain, Sweden, Switzerland, the United Kingdom, and the United States constitute this subsample. 
American Journal of Sociology

To assess the relationship of sex segregation to countries' levels of economic development, we use a measure of per capita GDP, with values logged (ln) to reduce the leverage of very high-income countries. These data are taken from the United Nations Development Programme and are for the year 1990, which should generally precede our graduates' choice of major.

\section{THE DESCRIPTIVE CONTOURS OF SEX SEGREGATION}

Field-specific sex segregation parameters $\left(A_{j}\right)$ are presented in table 1 . As explained above, negative scores indicate female underrepresentation (relative to the average field), and positive scores indicate female overrepresentation. Displayed in the final column are values on the summary sex segregation index, $A$, which gives the factor by which women or men are overrepresented in the average field in each country. A score of 1.00 on this index would indicate gender parity in all fields. All of the measures in table 1 are compositionally invariant, which means that they are insensitive to cross-national differences in overall female enrollment rates and in the relative sizes of educational fields.

The results in table 1 provide evidence of strong sex segregation that is consistent with previous studies of advanced industrialized societies (Charles and Bradley 2002, 2006). Among the most obvious cross-national similarities are uniformly negative coefficients in column 1, indicating underrepresentation of women in engineering programs in all 44 countries. Uniformly positive coefficients in column 3 , in contrast, point to acrossthe-board overrepresentation of women in the humanities and social sciences. The gender compositions of the other two fields are more mixed, with a tendency for men to be overrepresented in math/natural science and a tendency for women to be overrepresented in the health/other field. ${ }^{20}$ Patterns are in general consistent with the cultural depictions of masculine and feminine traits described above, with women overrepresented in more expressive and human-centered fields and men overrepresented in technical and math-intensive fields.

Cross-national differences are less predictable from the perspective of standard modernization accounts. The most integrated societies are not the most economically developed ones, and they are certainly not among those generally considered to be most progressive in terms of cultural gender ideology or public-sphere gender parity. The lowest overall levels of segregation (according to $A$ ) are found for Colombia, Bulgaria, and

${ }^{20}$ Part of the observed international variability undoubtedly reflects differences in the relative sizes of subfields within these categories (e.g., mathematics vs. the natural sciences). 
TABLE 1

Female Representation in Fields of Study: Sex-Segregation Parameters

\begin{tabular}{|c|c|c|c|c|c|}
\hline Country & $\begin{array}{c}\text { Engineering } \\
\text { (1) }\end{array}$ & $\begin{array}{c}\text { Math/Natural } \\
\text { Science } \\
\text { (2) }\end{array}$ & $\begin{array}{c}\text { Humanities/ } \\
\text { Social Science } \\
\text { (3) }\end{array}$ & $\begin{array}{c}\text { Health/ } \\
\text { Other } \\
\text { (4) }\end{array}$ & $\begin{array}{c}\text { Sex } \\
\text { Segregation } \\
\text { Index }(A)\end{array}$ \\
\hline Australia & -1.64 & -.09 & .63 & 1.10 & 2.82 \\
\hline Austria & -1.30 & -.27 & .88 & .69 & 2.38 \\
\hline Belgium ............. & -1.04 & -.31 & .87 & .48 & 2.09 \\
\hline Bulgaria $\ldots . . . . . .$. & -.65 & -.05 & .71 & -.02 & 1.62 \\
\hline Canada........... & -1.07 & .00 & 1.02 & .05 & 2.09 \\
\hline Chile $\ldots . . . \ldots \ldots \ldots$ & -1.30 & .14 & .79 & .38 & 2.20 \\
\hline Colombia .......... & -.63 & -.10 & .34 & .39 & 1.51 \\
\hline Cyprus & -1.56 & .37 & 1.51 & -.32 & 3.04 \\
\hline Czech Republic .... & -.99 & -.57 & .71 & .85 & 2.21 \\
\hline Denmark & -.99 & -.30 & .47 & .82 & 2.02 \\
\hline Finland & -1.67 & -.80 & 1.00 & 1.47 & 3.60 \\
\hline France $\ldots \ldots \ldots \ldots$ & -1.22 & -.14 & .96 & .41 & 2.24 \\
\hline Germany .............. & -1.72 & -.17 & .78 & 1.11 & 3.01 \\
\hline Greece & -1.05 & -.21 & .86 & .40 & 2.04 \\
\hline Hong Kong .......... & -1.87 & -.20 & 1.35 & .71 & 3.35 \\
\hline Hungary $\ldots \ldots \ldots \ldots$ & -1.21 & -.44 & 1.50 & .14 & 2.70 \\
\hline Indonesia $\ldots \ldots \ldots \ldots$ & -1.06 & .29 & .56 & .22 & 1.87 \\
\hline Iran $\ldots \ldots \ldots \ldots \ldots$ & -1.78 & .64 & .24 & .90 & 2.87 \\
\hline Ireland $\ldots \ldots \ldots \ldots$ & -1.54 & .49 & .99 & .06 & 2.58 \\
\hline Israel $\ldots \ldots \ldots \ldots \ldots$ & -1.39 & .20 & .64 & .55 & 2.27 \\
\hline Italy $\ldots \ldots \ldots \ldots \ldots$ & -1.69 & .43 & .77 & .49 & 2.67 \\
\hline Japan $\ldots \ldots \ldots \ldots$ & -1.48 & -.71 & 1.02 & 1.17 & 3.09 \\
\hline Jordan $\ldots \ldots \ldots \ldots$ & -1.30 & .48 & .57 & .25 & 2.13 \\
\hline Korea $\ldots \ldots \ldots \ldots$ & -1.71 & .33 & .94 & .44 & 2.76 \\
\hline Latvia $\ldots \ldots \ldots \ldots \ldots$ & -.86 & .12 & 1.19 & -.45 & 2.16 \\
\hline Macedonia ........... & -.89 & .54 & .38 & -.03 & 1.74 \\
\hline Malaysia & -1.16 & .46 & .77 & -.07 & 2.09 \\
\hline Netherlands & -1.34 & -.53 & .87 & 1.00 & 2.66 \\
\hline New Zealand ........ & -1.43 & -.04 & .70 & .77 & 2.42 \\
\hline Norway $\ldots \ldots \ldots \ldots$ & -1.14 & -.23 & .69 & .68 & 2.13 \\
\hline Philippines .......... & -1.08 & .19 & 1.01 & -.12 & 2.11 \\
\hline Portugal $\ldots \ldots \ldots \ldots$ & -1.11 & -.06 & .63 & .54 & 2.01 \\
\hline Romania $\ldots \ldots \ldots \ldots$ & -.66 & .56 & .37 & -.26 & 1.63 \\
\hline Russia & -1.46 & -.16 & 1.06 & .56 & 2.58 \\
\hline Slovakia $\ldots \ldots \ldots \ldots$ & -1.11 & -.26 & .58 & .79 & 2.12 \\
\hline Slovenia $\ldots \ldots \ldots \ldots$ & -1.42 & .14 & .91 & .37 & 2.38 \\
\hline South Africa ......... & -1.96 & .36 & .81 & .79 & 3.15 \\
\hline Spain $\ldots \ldots \ldots \ldots \ldots$ & -1.18 & -.13 & .73 & .57 & 2.12 \\
\hline Sweden $\ldots \ldots \ldots \ldots$ & -1.25 & -.52 & .78 & .98 & 2.52 \\
\hline Switzerland ........... & -1.88 & .09 & .97 & .81 & 3.11 \\
\hline Tunisia $\ldots \ldots \ldots \ldots$ & -.73 & -.14 & .38 & .49 & 1.62 \\
\hline Turkey & -1.12 & .28 & .10 & .74 & 1.98 \\
\hline
\end{tabular}


American Journal of Sociology

TABLE 1 (Continued)

\begin{tabular}{|c|c|c|c|c|c|}
\hline Country & $\begin{array}{c}\text { Engineering } \\
\text { (1) }\end{array}$ & $\begin{array}{c}\text { Math/Natural } \\
\text { Science } \\
\text { (2) }\end{array}$ & $\begin{array}{c}\text { Humanities/ } \\
\text { Social Science } \\
\text { (3) }\end{array}$ & $\begin{array}{l}\text { Health/ } \\
\text { Other } \\
\text { (4) }\end{array}$ & $\begin{array}{c}\text { Sex } \\
\text { Segregation } \\
\text { Index }(A)\end{array}$ \\
\hline United Kir & -1.50 & -.29 & .56 & 1.23 & 2.78 \\
\hline United States & -1.44 & .02 & .73 & .69 & 2.40 \\
\hline
\end{tabular}

Note. - Field-specific terms $\left(A_{j}\right)$ are defined in eq. (1). The summary $A$-index can be calculated as $\exp \left(1 / J \times \Sigma\left\{\ln \left(F_{j} / M_{j}\right)-\left[1 / J \times \sum \ln \left(F_{j} / M_{j}\right)\right]\right\}^{2}\right)^{1 / 2}$, where $F_{j}$ gives the number of women in field $j, M_{j}$ gives the number of men in field $j$, and $J$ is the number of fields.

Tunisia; the highest levels are found for Finland, followed by Hong Kong, South Africa, and Switzerland. International variability is striking even if we consider only engineering, the most sex-segregated field. In this case, we find that the male overrepresentation factor ranges from about 2 in Colombia and Bulgaria $(\exp [0.63]=1.88 ; \exp [0.65]=1.92)$ to about 7 in Switzerland and South Africa $(\exp [1.88]=6.55 ; \exp [1.96]=7.10)$. If anything, these results suggest a tendency for fields to be more segregated in highly affluent societies. Previous studies of educational and occupational distributions have yielded similarly counterintuitive patterns among advanced industrial countries (Charles and Bradley 2002, 2006; Charles and Grusky 2004). The current results, which are based on societies spanning a much broader range of economic development, cast further doubt on unidimensional evolutionary models of "women's status."

Countries differ not only in overall levels but also in patterns of sex segregation. For instance, among the three countries with the highest overall index scores, Finland shows strong female underrepresentation in both engineering and math/natural science, while Swiss and South African women are slightly overrepresented in the math/natural science field. In Italy, we find yet another pattern, with weak female representation in engineering coinciding with a strong absolute female presence in the math/ natural science category (see also Spitaleri 1996). ${ }^{21}$

\footnotetext{
${ }^{21}$ Because distributional unevenness is defined as deviations from average female-tomale ratios, there is a built-in tendency for negative intercorrelation among the $A_{j}$ terms in table 1. Interpretation of any given field-specific parameter is thus facilitated by comparison with its three counterparts. In the case of Italy, a strong presence of women in math/natural science can be inferred from the relatively modest deviations among values in columns 2, 3, and 4 and the large gap between columns 1 and 2 . Engineering is, in other words, the segregation outlier, while gender ratios in other three fields are much more uniform. Comparison with the corresponding percentage shares confirms this interpretation: women make up $12 \%$ of engineering students, $53 \%$ of math/natural science students, $62 \%$ of humanities/social science students, and $55 \%$ of health/other students in Italy. In Switzerland and South Africa, by contrast, the positive values for math/natural science can be largely attributed to extremely weak female representation in engineering (which pushes all other values into positive ter-
} 
Much historical and comparative research has been devoted to exploring contextual variability in gender designations and in the symbolic qualities attributed to occupations and academic fields (Cockburn 1985; Milkman 1987; Light 1999; Downey and Lucena 2005). Faulkner (2000), for example, finds that engineering is particularly inhospitable and unattractive to women in contexts where it is symbolically associated with muscularity and innate technical know-how-as opposed to brainpower and formal credentials. From this perspective, the extreme segregation of the Swiss engineering field may partly reflect its historical association with the technical vocations (and its resultantly muscular, blue-collar flavor). Although our disaggregate modeling approach allows us to describe patterns of sex segregation on a field-by-field basis, mechanisms driving country-specific deviations from general trends are best analyzed through qualitative case studies.

Before moving on to the explanatory models, it is instructive to consider bivariate associations of our sex segregation parameters with economic development, a variable that figures centrally in evolutionary accounts of gender inequality. Figure 1 plots this relationship for the four fields. Values displayed on the vertical axis are the field-specific segregation terms $\left(A_{j}\right)$ shown in table 1; values on the horizontal axis are per capita GDP, with values logged to reduce the leverage of very high-income countries. Simple correlation coefficients and probability values are shown in the bottom left-hand corner of each plot.

The pattern of association shown here suggests negative relationships of GDP with female representation in engineering and math/natural science and positive relationships with humanities/social science and health/ other. The correlation with GDP is weakest for the humanities/social science field, which shows tight clustering of segregation scores among developed countries.

The negative relationships found for the two mathematics-intensive fields are not simple artifacts of our measurement. Correlations of GDP with variables indexing women's absolute percentage share of students in each field reveal similar patterns. ${ }^{22}$ As noted above, we prefer to use our $A_{j}$ terms, because percentages depend strongly on overall female enrollment rates.

ritory). In Switzerland, e.g., only $4 \%$ of engineering students are female. Although women's share of math/natural science students $(24 \%)$ is not high by international standards, the extreme value for engineering means that it still registers as slightly above average by Swiss standards. This positive coefficient is nonetheless far smaller than those for humanities/social science and health/other (where women's percentage shares are $43 \%$ and $49 \%$, respectively).

${ }^{22}$ Zero-order correlations of GDP with \% female are -.43 for engineering, -.53 for math/natural science, .03 for humanities/social science, and .29 for health/other. 

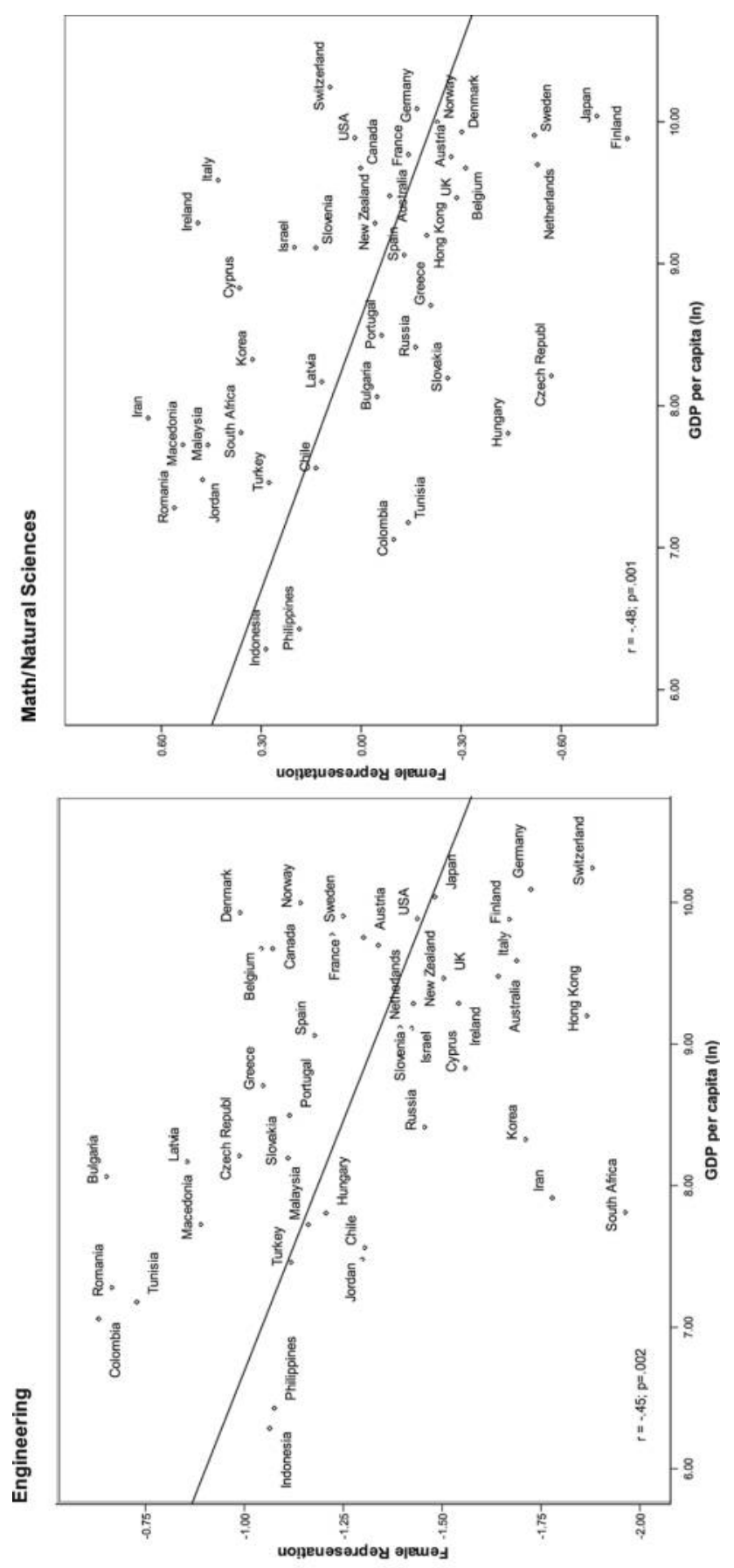

944 


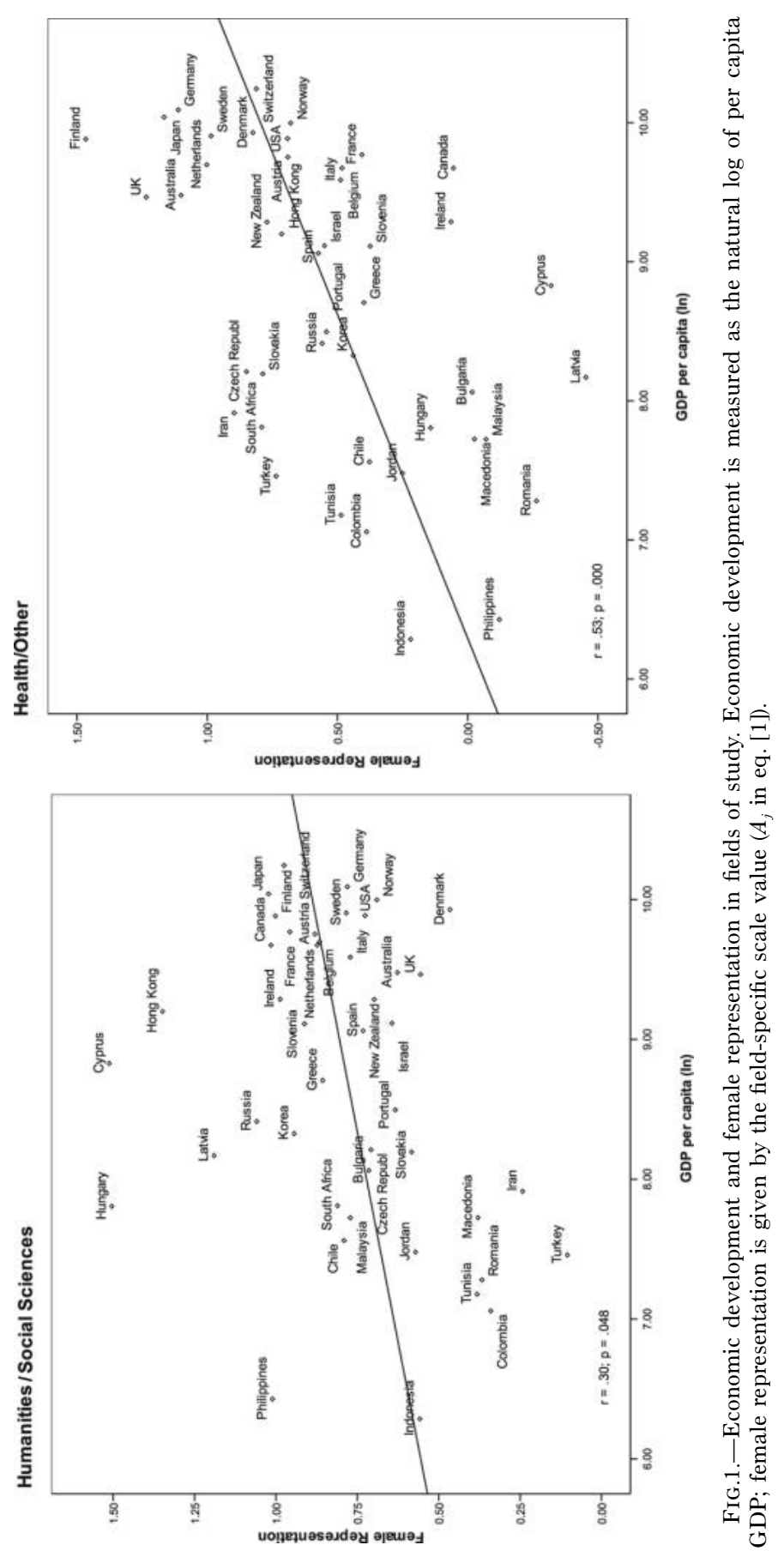

945 
A plot constructed to examine the relationship of economic development (GDP) with our $A$-index (not shown) confirms an overall positive association $(r=.43 ; P=.003)$. As expected, subgroup analyses indicate that this positive relationship between GDP and sex segregation is stronger among developing and transitional countries than among advanced industrial countries (.51 and .32, respectively). Correlations of GDP with Duncan and Duncan's (1955) widely used dissimilarity index $(D)$ are likewise positive. ${ }^{23}$

Results thus far are strongly at odds with accounts positing a general weakening of gender differentiation as economic modernization advances or universalistic values diffuse (Goode 1963; Parsons 1970; Jackson 1998, 2006; Ramirez and Wotipka 2001; Inglehart and Norris 2003; Baker and Letendre 2005). We next apply a multivariate log-linear modeling approach to examine the cultural and structural correlates of sex segregation by field of study and to explore possible discontinuities in these relationships.

\section{ACCOUNTING FOR CROSS-NATIONAL VARIATION}

Our explanatory models aim to account for cross-national variability with regard to the nine national-level covariates discussed above. Results for pooled (i.e., 44-country) models are considered first. We then explore differences between country groups in order to evaluate arguments suggesting distinct sex segregation regimes. We are particularly interested in assessing evidence for stronger effects of gendered curricular affinities and weaker effects of economic development in advanced industrial societies. Covariate means and standard deviations are shown in table 2, first for the pooled sample and then broken down by country group.

\section{Multivariate Analyses, Pooled Models}

Fit statistics for our first series of multivariate models are presented in table 3. Comparison of the independence and nine-covariate specifications (models 1 and 2) indicates that the country-level variables considered here together account for nearly half $(48.6 \%)$ of cross-national variability in sex segregation across these four fields of study. To better distinguish the relevant causal relationships, we identify a more parsimonious model (model 3) by sequentially deleting covariates until none can be omitted without causing a reduction in explanatory power that exceeds our $5 \%$

\footnotetext{
${ }^{23}$ Correlations with $D$ are $.58, .32$, and .23 for the less-developed/transitional, advanced industrial, and pooled samples, respectively.
} 
Sex Segregation

TABLE 2

Means (Standard Deviations) For Unstandardized Covariates

\begin{tabular}{|c|c|c|c|}
\hline Covariate & All Countries & $\begin{array}{c}\text { Developing/ } \\
\text { Transitional } \\
\text { Countries }\end{array}$ & $\begin{array}{c}\text { Advanced Industrial } \\
\text { Countries }\end{array}$ \\
\hline Economic development ........ & $\begin{array}{c}8.71 \\
(1.08)\end{array}$ & $\begin{array}{l}7.94 * * \\
(.77)\end{array}$ & $\begin{array}{l}9.72 \\
(.31)\end{array}$ \\
\hline Postindustrialism & $\begin{array}{r}-.01 \\
(.90)\end{array}$ & $\begin{array}{c}-.50 * * \\
(.88)\end{array}$ & $\begin{array}{c}.63 \\
(.38)\end{array}$ \\
\hline Labor force $\%$ female...$\ldots \ldots$. & $\begin{array}{l}39.56 \\
(8.29)\end{array}$ & $\begin{array}{l}37.89^{+} \\
(10.21)\end{array}$ & $\begin{array}{l}41.76 \\
(4.03)\end{array}$ \\
\hline Professions \%female & $\begin{array}{c}47.00 \\
(10.17)\end{array}$ & $\begin{array}{c}46.39 \\
(10.28)\end{array}$ & $\begin{array}{c}47.80 \\
(10.25)\end{array}$ \\
\hline Tertiary system size $\ldots \ldots \ldots \ldots$ & $\begin{array}{l}12.85 \\
(1.52)\end{array}$ & $\begin{array}{c}12.44 * \\
(1.52)\end{array}$ & $\begin{array}{l}13.40 \\
(1.37)\end{array}$ \\
\hline Educational diversification $\ldots .$. & $\begin{array}{c}28.89 \\
(19.33)\end{array}$ & $\begin{array}{c}28.90 \\
(21.57)\end{array}$ & $\begin{array}{c}28.87 \\
(16.49)\end{array}$ \\
\hline Graduates $\%$ female......... & $\begin{array}{l}52.44 \\
(6.83)\end{array}$ & $\begin{array}{l}52.47 \\
(7.87)\end{array}$ & $\begin{array}{l}52.41 \\
(5.38)\end{array}$ \\
\hline Girls' affinity for math $\ldots . \ldots$. & $\begin{array}{r}-3.50 \\
(5.38)\end{array}$ & $\begin{array}{r}-2.05 * \\
(4.47)\end{array}$ & $\begin{array}{r}-5.42 \\
(5.97)\end{array}$ \\
\hline Girls' math achievement ...... & $\begin{array}{r}-5.95 \\
(8.31)\end{array}$ & $\begin{array}{r}-6.32 \\
(9.89)\end{array}$ & $\begin{array}{r}-5.47 \\
(5.83)\end{array}$ \\
\hline$\ldots \ldots$ & 44 & 25 & 19 \\
\hline
\end{tabular}

NotE.-See app. A for covariate definitions. Two-tailed probability values are from $t$-tests for equality of means between the advanced industrial and developing/transitional country groups.

$+P<.10$.

$* P<.05$.

** $P<.01$.

threshold. In table 3 , comparison of the $L^{2}$ values from models 2 and 3 indicates that the elimination of five variables results in a relatively small reduction in explained variability (from $48.6 \%$ to $40.4 \%$ ), while conserving 15 degrees of freedom. ${ }^{24}$

Individual covariates' relative contribution to explained variability can be ascertained by comparing fit statistics for models with and without the respective covariates. The largest reduction in explanatory power, $27.5 \%([78,432-61,535] / 61,535=27.5)$, occurs upon deletion of postindustrialism from model 3 . The next largest effect is found for professions

\footnotetext{
${ }^{24}$ Our model-fitting procedure in fact resulted in the selection of those four variables that showed the strongest net effects in model 2 (details available on request). Use of a more liberal $3 \%$ deletion limit results in inclusion of the tertiary system size variable, which is associated with decreased female representation in engineering, increased female representation in math/natural science and health/other, and little change in parameter estimates for other variables shown in table 4 below.
} 


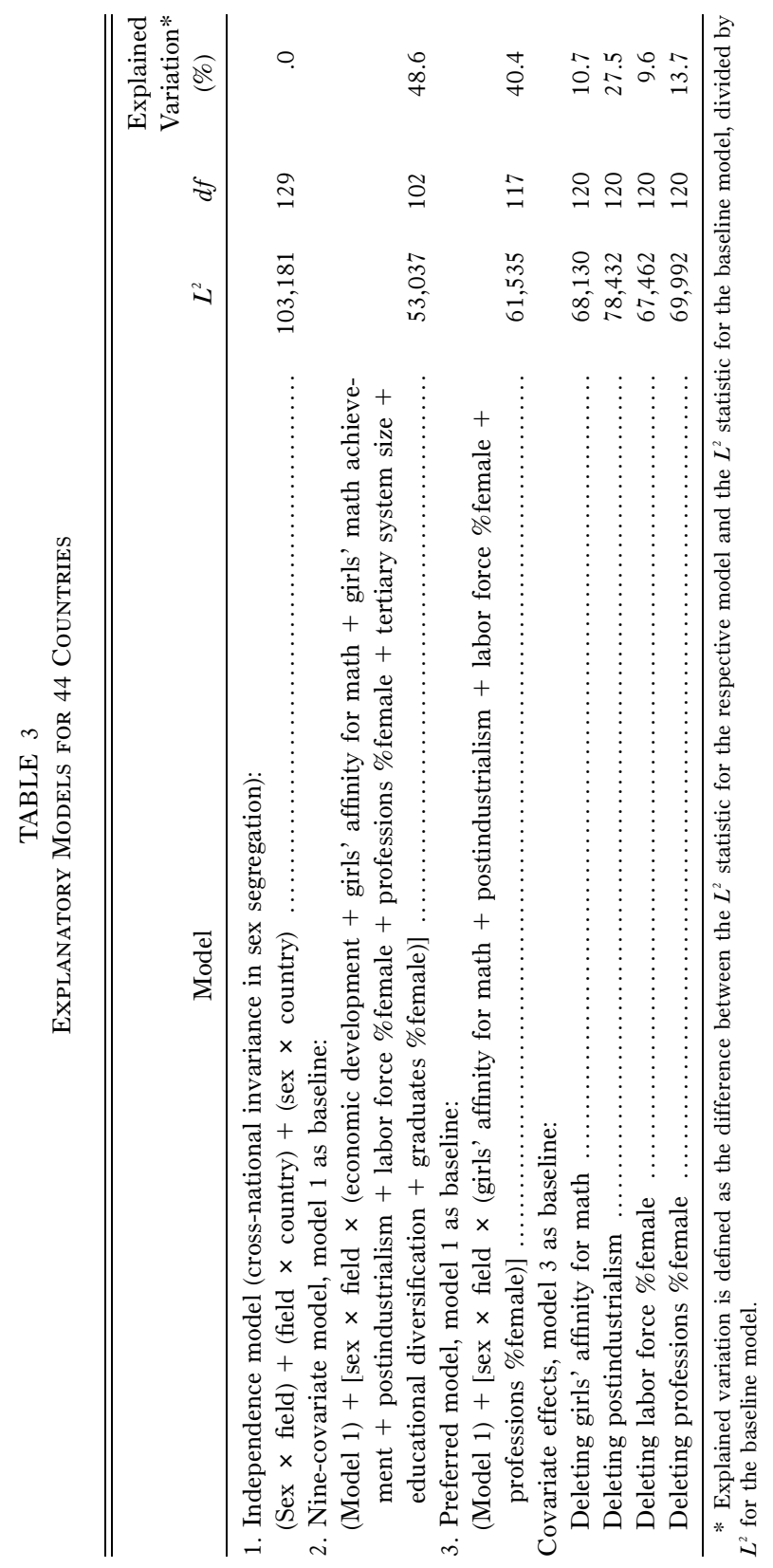


$\%$ female (which accounted for $13.7 \%$ of cross-national variability), followed by girls' affinity for math (10.7\%) and labor force \%female (9.6\%).

The absence of the GDP term from our preferred specification suggests that the overall bivariate association of sex segregation with economic development revealed in figure 1 is largely attributable to the correlation of GDP with one or more other covariates. As reported further on, however, a net GDP effect is measurable for the developing/transitional subsample.

What about the direction of observed effects? Table 4 shows the relationship of each covariate to women's representation in the four fields. To facilitate comparison of effect sizes within the columns of this table, parameter estimates are computed using standardized covariates (i.e., with variables measured in standard deviations from the pooled mean). The resultant coefficients give the change in female representation $\left(A_{j}\right)$ that is associated with a one-standard-deviation increase in the respective covariate.

Consistent with understandings of sex segregation as an outcome of gender-differentiated dispositions or cultural schemas, girls' relative affinity for mathematics is positively related to female representation in the two mathematics-intensive fields and negatively associated with female representation in the two other fields. However, fit statistics reported in table 3 indicate that the overall effect of this variable is small compared to some of the economy-related indicators, particularly postindustrialism.

The effects of postindustrialism, shown in the second row of table 4, are mostly segregative, as expected. Most notably, we find that a onestandard-deviation increase in this index (roughly equivalent to the difference between Norway and Russia) is associated with an increase of $22 \%$ in women's representation in the health/other field $(\exp [.20]=1.22)$. This is likely attributable to the expansion and feminization of health care industries in postindustrial economies and the proliferation of the corresponding degree programs. Coefficients also show negative relationships of our postindustrialism index with female representation in both engineering and math/natural science, as would be predicted by arguments linking service-sector expansion and economic rationalization to consolidation of female-labeled "occupational ghettos" (Oppenheimer 1970; Charles and Grusky 2004). We were surprised to find a weak negative association of postindustrialism with female representation in humanities and social science programs, since these credentials are applicable to administrative careers and many large social, human, and financial service occupations. We note that humanities and social science programs do tend to be more heavily feminized in countries characterized by strong female participation in the labor market and in the professions (see the coefficients in the third and fourth rows of table 4). Since administrative and financial 
American Journal of Sociology

TABLE 4

Standardized Parameter Estimates from Preferred Model for 44 Countries

\begin{tabular}{lcccc}
\hline \hline $\begin{array}{c}\text { Covariate } \\
\text { (Explained Variation) }\end{array}$ & Engineering & $\begin{array}{c}\text { Math/ } \\
\text { Natural Science }\end{array}$ & $\begin{array}{c}\text { Humanities/ } \\
\text { Social Science }\end{array}$ & $\begin{array}{c}\text { Health/ } \\
\text { Other }\end{array}$ \\
\hline $\begin{array}{l}\text { Girls' affinity for math } \\
(10.7 \%) \ldots \ldots \ldots \ldots \ldots \ldots\end{array}$ & .02 & .15 & -.06 & -.11 \\
$\begin{array}{l}\text { Postindustrialism } \\
(27.5 \%) \ldots \ldots \ldots \ldots \ldots \ldots\end{array}$ & -.11 & -.06 & -.04 & .20 \\
$\begin{array}{l}\text { Labor force } \% \text { female } \\
(9.6 \%) \ldots \ldots \ldots \ldots \ldots \ldots .\end{array}$ & -.01 & -.11 & .18 & -.05 \\
$\begin{array}{l}\text { Professions } \% \text { female } \\
(13.7 \%) \ldots \ldots \ldots \ldots \ldots \ldots\end{array}$ & .10 & -.04 & .08 & -.14 \\
\hline Note. - Values are the relevant covariate interaction terms from model 3 of table 3. Parameter es-
\end{tabular}
timates are calculated with all covariates measured in standard deviations from the 44-country mean.

service jobs are widely distributed across industries (including in the traditional manufacturing and production sectors), it is possible that women's investment in the associated credentials depends more on their perceived market opportunities than on the industrial composition of the economy.

Overall, the results provide mixed support for rational-choice and neoinstitutionalist accounts, both of which imply lower levels of sex segregation where female economic opportunities are greater (albeit each for different reasons). We find that engineering programs are indeed more gender integrated in contexts where more professional employees are women. But no such effect is found for the math/natural science category. Female labor force participation and representation in the professions show segregative effects as well-for example, in the humanities/social science field.

We have also examined zero-order effects through a series of four univariate models (one for each covariate in the preferred model). Parameter estimates from these models, available on request, correspond closely to those shown in table $4 .^{25}$

In sum, the results of our pooled 44-country analyses suggest that (1) the association of sex segregation with economic development revealed in figure 1 is at least partly attributable to cross-national differences in economic structure (i.e., postindustrialism) and (2) aggregate-level gender differentiation in affinity for mathematics does help predict female representation in math-intensive fields (especially in math and the natural sciences). We next explore the uniformity of these relationships across contexts, specifically whether determinants of sex segregation differ be-

${ }^{25}$ Exceptions are positive zero-order associations of postindustrialism with female representation in the humanities and social sciences and of labor force \%female with female representation in the health/other field. 
tween advanced industrial and developing/transitional societies, as we have suggested above.

\section{Multivariate Analyses, by Country Group}

Before presenting our next series of multivariate models, a striking difference in subgroup means warrants mention. Consistent with our argument positing positive feedback effects between sex segregation and gendered curricular affinities, the descriptive statistics displayed in table 2 reveal a significantly larger gender gap in expressed affinity for mathematics in advanced industrial than in developing/transitional societies ( $t$-ratio $=2.15 ; P=.037)$. In the former group, the percentage of girls who claim to "like math" or "like math a lot" is on average 5.42 points lower than the percentage of boys who make this claim. This gap is only 2.05 points in developing/transitional societies. As can be seen in table 5 , large, statistically significant differences between the country groups also exist on related indicators, including gender gaps in professed affinity for science ("I like science") and aspirations for math-related careers ("I would like to work in a job involving mathematics"). These gaps do not correspond to simple differences in girls' mathematical achievement; in fact, table 2 shows that the math achievement gap is slightly smaller in the more economically developed countries. ${ }^{26}$ The mean differences shown in table 5 provide preliminary evidence that national prosperity and the rise of self-expressive value systems promote development (or expression) of gender-differentiated curricular dispositions. The causal processes underlying cross-national variability in such dispositions among women and men is an important area for future research. We return to this issue further on.

Table 6 shows fit statistics for the independence, nine-covariate, and preferred models, broken down by country group. The nine covariates together account for $75.3 \%$ and $68.0 \%$ of cross-national variability in sex segregation by field of study in developing/transitional and advanced industrial countries, respectively (models 2 and 5). For each country group, our model-selection procedure yields a four-covariate preferred specification (models 3 and 6). Deletion of five variables results in a modest

\footnotetext{
${ }^{26}$ See also Shapka and Keating (2003) on the weak association between attitudes and achievement at the individual level.
} 
American Journal of Sociology

TABLE 5

Female-Male Gap in Affinity for Mathematics and Science, By COUNTRY Group

\begin{tabular}{|c|c|c|}
\hline Survey Item & Developing/Transitional & Advanced Industrial \\
\hline I like math & $\begin{array}{r}-2.05^{*} \\
(4.47)\end{array}$ & $\begin{array}{r}-5.42 \\
(5.97)\end{array}$ \\
\hline $\begin{array}{l}\text { I would like to work in a job } \\
\text { involving math } \ldots \ldots \ldots \ldots . . .\end{array}$ & $\begin{array}{l}-3.62 * * * \\
(2.96)\end{array}$ & $\begin{array}{r}-10.77 \\
(6.02)\end{array}$ \\
\hline I like science & $\begin{array}{c}-1.91 * * \\
(3.45)\end{array}$ & $\begin{array}{c}-7.15 \\
(6.96)\end{array}$ \\
\hline$N$ & 25 & 19 \\
\hline
\end{tabular}

NotE. - Values are the mean difference (girls - boys) between the percentage of eighth-grade girls and the percentage of eighth-grade boys that "agrees" or "strongly agrees" with the corresponding statement (see app. A on data and measures). Values in parentheses are SDs. Asterisks give two-tailed probability values from $t$-tests for equality of means between country groups.

$* P<.05$.

** $P<.01$.

*** $P<.001$.

reduction in \%explained variation-to $70.8 \%$ and $53.5 \%$, respectivelywhile conserving 15 degrees of freedom. ${ }^{27}$

Table 7 shows field-specific parameter estimates and covariate effect sizes (\%explained variation) for the preferred models ( 3 and 6 ) in table 6 , by country group. We again use standardized covariates (measured this time in standard deviations from the respective subgroup means). Among developing and transitional countries, the most powerful explanatory effects are economic development (which accounts for $22.2 \%$ of crossnational variation), professions \%female $(15.0 \%)$, tertiary system size $(11.0 \%)$, and labor force \%female (10.5\%). Among advanced industrial countries, the strongest effect is found for girls' affinity for math $(28.3 \%$ of cross-national variation), followed by postindustrialism (19.3\%), educational diversification (12.1\%), and girls' math achievement (5.3\%). Female enrollment rates showed weak effects in both subsamples, perhaps because of the countervailing pressures discussed earlier ${ }^{28}$ It is notable

${ }^{27}$ Application of a more liberal $3 \%$ standard resulted in an identically specified model for developing and transitional countries. For advanced industrial countries, it resulted in the retention of three additional covariates (economic development, labor force $\%$ female, and professions \%female), but no substantive changes in existing covariate effects. Interestingly, the effects of economic development on female representation in math/natural science and health/other differ in direction from those found for the lessdeveloped subsample, providing further evidence that material affluence is not associated with net increases in sex segregation among advanced industrial societies.

${ }^{28}$ Specifically, we suggested that integrative effects associated with women's cultural empowerment may be offset by less-rigorous culling and by efforts of educational policy makers to accommodate women as a group. 
Sex Segregation

TABLE 6

Explanatory MOdels, By COUNTRy Group

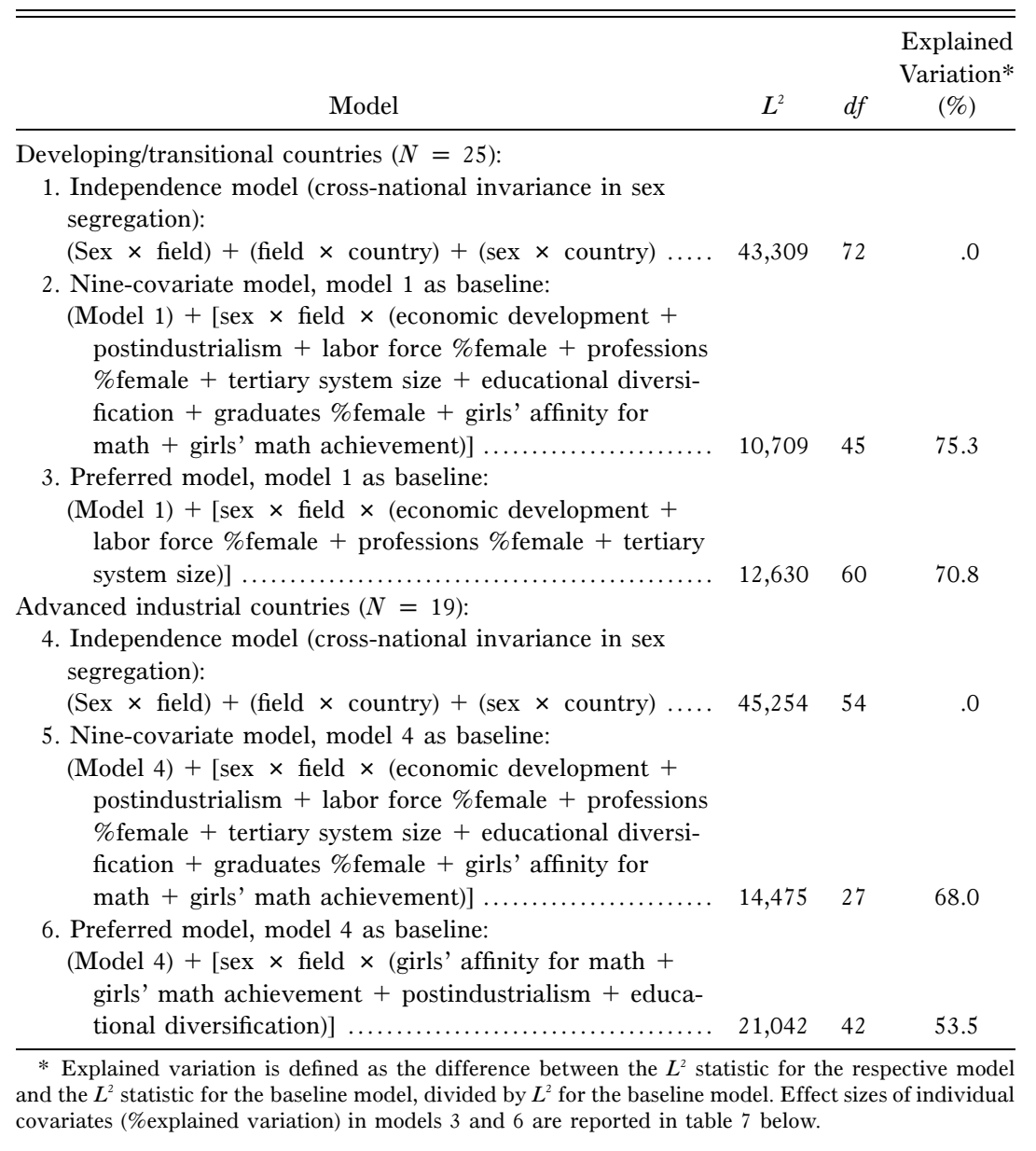

that our preferred models share no common covariates. This finding supports our argument positing distinct sex segregation "regimes" in advanced industrial and developing/transitional societies. These regimes are described below.

\section{Less-Developed and Transitional Societies}

Coefficients for the developing/transitional subsample in table 7 show uniformly segregative effects of economic development (GDP) on the four fields. Figures for explained variation in fact reveal that GDP, with a 
American Journal of Sociology

TABLE 7

Standardized Parameter Estimates from Preferred Models, By Country Group

\begin{tabular}{|c|c|c|c|c|}
\hline $\begin{array}{c}\text { Covariate } \\
\text { (Explained Variation) }\end{array}$ & Engineering & $\begin{array}{c}\text { Math/ } \\
\text { Natural } \\
\text { Science }\end{array}$ & $\begin{array}{c}\text { Humanities/ } \\
\text { Social } \\
\text { Science }\end{array}$ & $\begin{array}{c}\text { Health/ } \\
\text { Other }\end{array}$ \\
\hline \multicolumn{5}{|l|}{ Developing/transitional countries (model 3): } \\
\hline Economic development (22.2\%) & -.29 & -.06 & .13 & .22 \\
\hline Tertiary system size (11.0\%) & -.27 & -.01 & .14 & .15 \\
\hline Labor force $\%$ female $(10.5 \%)$ & .29 & -.17 & .06 & -.18 \\
\hline Professions \%female (15.0\%) & -.10 & -.04 & .21 & -.07 \\
\hline \multicolumn{5}{|l|}{ Advanced industrial countries (model 6): } \\
\hline Girls' affinity for math (28.3\%) & .09 & .27 & -.04 & -.32 \\
\hline Girls' math achievement (5.3\%) & -.03 & .07 & .06 & -.10 \\
\hline Postindustrialism $(19.3 \%) \quad \ldots \ldots \ldots \ldots \ldots$ & -.04 & -.10 & -.11 & .25 \\
\hline Educational diversification $(12.1 \%) \ldots \ldots$ & .06 & -.02 & .14 & -.18 \\
\hline
\end{tabular}

NOTE. - Values are covariate interaction terms from models 3 and 6 of table 6. Parameter estimates are calculated with all covariates measured in standard deviations from the subgroup means. Explained variation for each covariate gives the percentage change in the $L^{2}$ statistic that occurs with its deletion from the respective baseline model (model 3 or model 6).

value of $22.2 \%$, is the best single predictor of distributions across fields of study for this group. The effects on engineering are especially large, where a one-standard-deviation increase in the natural log of per capita GDP (i.e., the approximate difference between Romania and Bulgaria) corresponds to a decrease of $25 \%$ in female representation $(\exp [-.29]=$ $.75)$.

These economic development effects are very robust. In a series of supplementary models, we find no evidence that our GDP term is absorbing effects of correlated but causally unrelated variables. For example, we have tested and rejected arguments holding that the GDP effect is attributable to cross-national variability in the prestige of science, or that it reflects differential linkages to the global institutions that promote gender-egalitarian agendas. ${ }^{29}$ To account for the longer tradition of female scientific and professional employment in formerly Soviet states (Van der Lippe and Van Dijk 2002), we also considered GDP effects net of an Eastern Europe indicator variable. This resulted in no substantive changes in the effects of GDP or other covariates in the model. ${ }^{30}$ Demographic variables, such as national fertility rates and average age at

${ }^{29} \mathrm{We}$ measured the former using international science citation rates and the latter using memberships in international organizations. For arguments on world-cultural linkages and the status of science, see Schofer and Meyer (2005) and Drori et al. (2003).

${ }^{30}$ Consistent with patterns shown in fig. 1, the results of this multivariate model showed relatively strong representation of Eastern European women in engineering, but also in the humanities and social sciences. 
first marriage, were explored as well. In no case were the segregative relationships with GDP eliminated. ${ }^{31}$ The economic development effects observed for this subsample may be due to diminishing economic constraints on women's educational choices with growing national prosperity. As we demonstrate below, however, this effect does not hold for advanced industrial countries. We discuss the context dependence of this relationship further on.

Interestingly, our variable measuring mathematical affinity does not survive deletion for this country group. The relationship between curricular distributions and gender-differentiated affinities that was revealed in table 4 (pooled model) thus holds primarily for advanced industrial societies, as expected.

Regarding our two indicators of female economic opportunity (labor force \%female and professions \%female), results are again mixed-some segregative, some integrative. As was the case for the pooled models, both indicators are negatively related to female representation in math/natural science and health/other, and both are positively related to female representation in the humanities and social sciences. The strongest support for rational-choice and neoinstitutionalist arguments can be found in the positive association between female labor force participation and women's presence in engineering. ${ }^{32}$ This positive effect of labor force participation is, however, partially offset by a negative effect of professions \%female on engineering. It would appear that increased professional opportunities in less-developed and transitional societies more often lead women to invest in credentials applicable to teaching and legal careers than to technical or scientific careers.

Finally, we find support for arguments linking sex segregation to structural features of educational systems. In less economically developed countries, expansion of higher education (but not structural diversification) is associated with increased segregation of some fields. We suggested earlier that class or academic prowess may trump gender in small and highly

\footnotetext{
${ }^{31} \mathrm{We}$ also considered the possibility that the weaker sex segregation in low-GDP countries is attributable to men's greater tendency to study science and engineering abroad. Because data on rates of international study are missing or unreliable for many developing countries, this relationship could not be formally modeled. However, informal comparison of available figures lends little support to this hypothesis because the numbers of students studying abroad are too small to sufficiently affect gender ratios.

${ }^{32}$ This effect of female labor force participation differs in direction from that reported for the pooled model. We speculate that women living in societies characterized by low levels of material prosperity and high levels of female employment will more often invest in credentials that will secure access to occupations that they (and their parents) believe will be lucrative and supportive of national economic development. Engineering is likely one such occupation.
} 
selective systems of higher education. The covariate effects displayed in table 7 indicate that system size is indeed negatively associated with women's representation in engineering and positively associated with women's representation in both humanities/social science and health/other for this country group. No such effects are found for advanced industrial countries, however. It may be that the segregative influence of large systems is greater in developing/transitional societies because curricular and career choices are less widely understood as self-expressive acts in these contexts. In advanced industrial societies, by contrast, the culling effects associated with small system size may not be strong enough to offset widely diffused cultural ideals of gendered self-expression, which influence even the most elite, proficient students.

To insure that our results are not disproportionately influenced by extreme values, we have conducted robustness checks using a sample that excludes Iran, Jordan, and Tunisia, all potential outliers on the labor force $\%$ female variable. In no case did the direction of parameter effects differ from those shown in table 7 (or table 4 for the pooled models). In addition, we have assessed zero-order effects by computing four univariate models (one for each covariate in model 3). With the exception of minor differences for the two employment-related variables, these yield parameter estimates consistent with those shown in table 7 .

\section{Advanced Industrial Countries}

The best single predictor of gender distributions across fields of study in advanced industrial societies is the size of the gender gap in affinity for mathematics, which accounts for $28.3 \%$ of cross-national variability in sex segregation (table 7). All field-specific effects of this covariate are consistent in direction to those displayed in table 4 for the pooled model. But effect sizes are much larger this time. The largest positive coefficient is found for the math/natural science field, where an increase of one standard deviation in girls' affinity for math increases female representation by approximately $31 \%(\exp [.27]=1.31)$. The same increase produces a decrease of $27 \%$ in female representation in the health/other field $(\exp [-.32]=.73)$. Effects of affinity for science (not shown) closely approximate those presented for mathematics. ${ }^{33}$

With respect to postindustrialism, we again find the most pronounced effect for the health/other category. The effect is quite large, with a onestandard-deviation increase in the postindustrialism index (approximately

${ }^{33}$ We prefer the mathematics variable because the study of advanced mathematics is required for most engineering and natural science degrees and because data on affinity for science were missing for one country (Austria). 
the difference between Switzerland and Sweden) corresponding to an increase of $28 \%$ in women's representation in the health/other field $(\exp [.25]=1.28)$. Postindustrial economic restructuring appears to increase the propensity for women in advanced industrial countries to pursue credentials required for health-care-related careers, for example, as nurses, medical technicians, and doctors. As with the pooled models, postindustrialism is negatively related to female representation in the other three fields, in part because the exceptionally strong effect for health/other pushes all other coefficients-including that for humanities/social science-into negative territory. ${ }^{34}$

As expected, the effects of tertiary educational diversification were stronger in advanced industrial than in developing/transitional societies. Effects vary by field in ways that are not clearly segregative or integrative, however. Coefficients for the two male-typed categories (engineering and math/natural science) show mutually opposing signs, as do those for the two female-typed categories (humanities/social science and health/other). The largest effects are found for the latter two fields. ${ }^{35}$ The strong positive effect of educational diversification on female representation in the humanities and social sciences was expected, since this curricular category includes female-labeled programs in business administration, service trades, and preprimary education, many of which are rapidly expanding at the nonuniversity (two-year) degree level. The proliferation of these newer nonuniversity-track programs may result in the diversion of some women away from more established two- and four-year programs in nursing and medical technology (which would help account for the negative effect of diversification found for the health/other category). Coefficients for the engineering and math/natural science categories are considerably smaller. Women show a tendency for stronger representation in engineering in systems with a larger nonuniversity sector, perhaps because diversification implies "upgrading" to the tertiary educational level of more vocationally oriented engineering trades, such as technical drafting and surveying.

Effects of girls' math achievement are relatively small and inconsistent across the two mathematically oriented fields. It is noteworthy that effects

\footnotetext{
${ }^{34}$ Recall that these terms are constrained to sum to zero within each country.

${ }^{35}$ Effects found here for the humanities/social science and health/other categories correspond closely, in both size and direction, to those documented previously for advanced industrial societies (Charles and Bradley 2002, table 4b). With respect to the engineering and math/natural science fields, both studies find relatively small diversification effects, but the direction of these effects differs across studies. Possible reasons for this disparity include the larger sample of advanced industrial countries used for the present analysis (19 compared to 12), and the different model specifications (tertiary educational diversification is the only common covariate).
} 
of mathematical affinities hold net of any aggregate-level gender differences in achievement.

Our preferred specification for this country group includes no GDP term. We surmise that the positive bivariate correlations reported above for this country group are largely attributable to the larger service sectors and larger gender gaps in curricular affinities in advanced industrial societies. In a series of four univariate models, the gender gap in affinity for mathematics shows the largest zero-order effect, with the direction of field-specific terms in all cases consistent with those shown in table 7 (results available on request). ${ }^{36}$

\section{Summary of Findings from Multivariate Models}

Rather than linear modernization effects, our results reveal two distinct sex segregation regimes, with different causal mechanisms influencing the gender composition of educational fields in advanced industrial and developing/transitional societies. In the former group, the most important single predictor is the size of the gender gap in expressed affinity for mathematics. In societies where girls report a stronger aversion to mathematics (relative to boys), fewer women in fact complete degrees in mathintensive fields. For the developing/transitional group, the largest effect is found for per capita GDP. But contrary to the predictions of evolutionary theories, we find a negative effect of this variable on women's representation in typically male-labeled technical and scientific fields and a positive effect on the human-centered and expressive fields. We discuss these major findings in our concluding section.

Modern structural features of labor markets and educational systems also show many segregative effects, although the nature of these effects varies across country groups. In less-developed and transitional countries, female representation in humanities and social science programs is positively associated with three modern structural features: high rates of female employment, a strong presence of women in the professions, and large systems of higher education. From a neoclassical economic perspective, these relationships are not surprising; humanities and social science degrees support entry into teaching, law, and business occupations, which are often among the first to draw large numbers of college-educated women. In advanced industrial countries, women's representation in the health/other field is stronger where economies are more highly rationalized and service-based. This result is consistent with previous research linking

${ }^{36}$ More substantial differences between zero-order and multivariate parameter esti-
mates are found for other covariates. These are largely attributable to a relatively
strong correlation between postindustrialism and educational diversification $(r=.51)$. 
postindustrial economic restructuring to gender-differentiated career paths (Oppenheimer 1970; Charles 2005). Results suggest, moreover, that diversification of higher education promotes increased concentration of women in humanities and social science fields (but also in engineering) in advanced industrial societies.

\section{DISCUSSION AND CONCLUSION}

Enormous growth in female university enrollments since World War II has been accompanied by dramatic improvements on many other dimensions of women's status. But the results of the present analysis provide little evidence that these gains represent part of a secular degendering of educational institutions. In fact, we find that sex segregation by field of study is on average more pronounced in advanced industrial societies. Our analyses reveal important discontinuities in the relationship between economic development and sex segregation, however. Specifically, they point to the operation of distinct sex segregation regimes in materialist and postmaterialist contexts.

In developing and transitional societies, multivariate models confirm a net tendency for greater segregation as per capita GDP increases. We suggest that economic modernization does not have the degendering effect that modernization scholars expect because realization of any preference for lower-paid female-typed careers is more constrained (and less culturally legitimate) under conditions of greater scarcity. ${ }^{37}$ From this perspective, increasing sex segregation may reflect decreasing normative and material pressures for university-educated persons, regardless of gender, to obtain credentials in lucrative scientific and technical fields and to build human capital in fields (like engineering and the natural sciences) that are deemed crucial for national development and competitiveness in the international economy. In other words, instrumental goals of material security and national economic development are decreasingly central to curricular decisions (by students themselves, parents, family members, and educational gatekeepers) as national prosperity grows. But this segregative GDP effect is measurable only up to a point.

Among advanced industrial societies, further increases in national prosperity (GDP) do not exert a segregative effect on curricular distributions because existential security is now widely taken for granted at the mass-

\footnotetext{
${ }^{37}$ Consistent with this argument, Gharibyan (2006) attributes Bulgarian women's strong representation in computer science programs to the absence in that culture of an expectation that one will "love" one's job. Instead, she says, both men and women are attracted to computer science because of its potential to provide a financially secure future.
} 
societal level. Strongly diversified university curricula are commonly celebrated as instruments for individual self-realization in these contexts. Sacrificing material rewards in order to pursue a passion (or presumed passion) is more culturally legitimate-especially for women, who are generally not expected to be primary breadwinners. As individuals seek to express their essential (male and female) selves, the gender labeling of academic fields intensifies, and distributions across these fields become more closely aligned with gender-specific curricular dispositions. Crossnational variability in girls' relative mathematical affinities (rather than variability in economic capacities to realize such affinities) thus becomes a decisive determinant of gender distributions across curricular fields in advanced industrial segregation regimes.

Mean difference scores showing that adolescents' dispositions toward mathematics are more gender typed in advanced industrial than in developing and transitional societies suggest that gender-essentialist ideology may indeed interact with self-expressive ideals to generate powerful selffulfilling prophesies. Because beliefs about innate gender difference are so pervasive and so deeply institutionalized, self-expressive value systems not only promote realization of gendered affinities, but also likely encourage their development and performative display. The resultant increases in the sex segregation of educational fields and labor markets reinforce stereotypes of men as naturally more math-inclined and analytical and of women as naturally suited for activities involving personal interaction and nurturance. Real or presumed female aversion to mathematics will in turn more often translate into gender-differentiated curricular distributions in cultural contexts where self-expression is highly valued. Self-expressive ideology, gender essentialism, and material security thus combine to support a positive-feedback system. Data permitting, future research should explore these dynamic effects directly through analysis of historical trends in select national contexts.

Structural trends in labor markets and educational systems have further encouraged sex segregation by field of study in advanced industrial societies and elsewhere. Girls may be less likely to pursue (and express affinity for) mathematics and science curricula when a wide array of female-labeled and potentially fulfilling career options present themselves in the service sector of the economy. Similarly, we suspect that postwar efforts to increase female university enrollment and expand programmatic choice have encouraged a closer alignment between gender identities, curricular dispositions, and programmatic choices. In other words, there 
is much room for societal influence in the cultivation and expression of individual preferences. ${ }^{38}$

The uneven progress toward gender equalization in higher education may be attributable to different cultural logics underlying different forms of inequality. Modern universalistic ideals are clearly inconsistent with the blatant discriminatory practices that have historically supported male enrollment monopolies in elite universities and colleges. But the liberal individualistic variety of egalitarianism that predominates today in advanced industrial societies emphasizes formal procedural equality, a principle that can exist quite comfortably alongside essentialist representations of gender difference. Sex segregation by field of study is ideologically compatible with liberal egalitarianism because it appears to reflect the naturally distinct preferences and aspirations of formally equal men and women. Our findings challenge notions of gender equality as a unitary entity and contribute to an emergent body of literature that advances a multidimensional conceptualization of women's status (Bradley and Khor 1993; Charles and Grusky 2004; Lopez-Claros and Zahidi 2005; Mandel and Semyonov 2006; Wiseman 2008).

\section{Should We Be Concerned?}

Sex segregation by field of study is widely understood to represent the outcome of free choices by autonomous, but fundamentally gendered, individuals. It thus corresponds to a "different but equal" version of gender egalitarianism that resonates strongly with citizens of even the most ideologically progressive societies. Should we, then, be concerned about whether men and women receive degrees in different fields? We suggest three reasons why sex segregation by field of study should be of more than theoretical interest.

The first reason is that segregation may have feedback effects. Gender differentiation of life activities reinforces essentialist stereotypes and preferences and establishes boundaries of normative behavior so that subsequent generations of boys and girls do not perceive a full range of educational, career, and life options.

A second reason for concern is that "separate but equal" allocational principles rarely work well in practice, especially when power differentials come into play. A large American literature on the payoff to human capital investments suggests that degrees in female-dominated fields such as the humanities and social sciences translate into considerably lower incomes than do scientific and technical degrees (National Center for Educational

\footnotetext{
${ }^{38}$ A recent cross-national analysis by Penner (2008) suggests that gender differences in math achievement are also related to social and cultural factors.
} 
American Journal of Sociology

Statistics 2003; Roksa 2005). The causal direction of the association between occupational pay and gender composition remains an open empirical question.

Finally, sex segregation by field of study is of concern because of severe shortages of technical and scientific personnel in both industrializing and industrialized countries. International organizations, government agencies, and professional societies have recently been issuing dire warnings that the "wastage" of competent women may undermine national competitiveness or increase reliance on outsourcing and immigrant labor (UNESCO 1996b; National Academy of Engineering 2004; National Academy of Sciences 2005; European Commission Directorate-General for Research 2006).$^{39}$ Women thus represent an untapped reserve army of (native-born) engineers, natural scientists, and technicians. Their recruitment to these fields is increasingly treated as an urgent priority in many countries. ${ }^{40}$

\section{What Can Be Done?}

The results of this and other studies suggest that educators, parents, and outreach agents who wish to encourage female entry into technical and math-intensive fields should first and foremost avoid reinforcing stereotypes about what boys and girls "like" and what they are good at. There is much evidence that widespread cultural beliefs about gender difference influence individuals' preferences and perceptions and bias evaluations of self and others (see, e.g., Collis and Williams 1987; Eagly, Wood, and Diekman 2000; Correll 2001, 2004; Fenstermaker and West 2002; Lee 2002; Ayalon 2003; Pronin, Steele, and Ross 2003; Ridgeway and Correll 2004). A shrinking gender gap in achievement and an observed convergence in boys' and girls' high school math and science coursetaking may be the first signs of a cultural shift in the United States (Goldin, Katz, and Kuziemko 2006), but it is also striking that capable American girls and women continue to express doubts about their mathematical abilities (Eccles 2007; Noel-Levitz 2007). Because gender-essentialist beliefs are so deeply held and so widely institutionalized in advanced industrial soci-

\footnotetext{
${ }^{39}$ From a more essentialist perspective, some scholars have suggested that entry of more female scientists will transform the nature of science, broadening the focus of research and altering the framework by which research findings are interpreted and linked to practice (e.g., Fox 2001; Bystydzienski and Bird 2006).

${ }^{40}$ Policy initiatives focus heavily on integrating engineering, computer science, and other physical science fields. The gender gap tends to be considerably smaller in the life sciences (National Science Foundation 2001; Jacobs 2003; OECD 2004; England et al. 2007).
} 
eties, any ideologically driven integration of academic fields is likely to occur slowly.

Meanwhile, strategic changes in the organization of secondary and postsecondary education may help to reduce gender labeling of fields, limit the influence of gender stereotypes on curricular trajectories, and create opportunities for building communities of mathematically and technically competent girls and women. Previous comparative and historical research provides evidence that limitations on curricular choice-either through universal requirements for math and science coursework throughout secondary school or through stronger reliance on merit-based curricular placement-results in stronger representation of women in scientific and technical fields and a weaker influence of peers on students' educational aspirations (OECD 1986; Barinaga 1994; Hanson, Schaub, and Baker 1996; Buchmann and Dalton 2002). ${ }^{41}$ Such restrictive educational policies are strongly at odds with practices in the United States and many other advanced industrial societies, where high-level math and science are optional and "freedom of choice" is widely celebrated (Frank and Meyer 2002; Schwartz 2004). But social pressures to conform to gender norms often peak during adolescence (Entwisle and Greenberger 1972; Gaskell 1985). Allowing girls to opt out of science and mathematics courses during their teenage years increases sex segregation in higher education by limiting subsequent curricular options (Charles et al. 2001; Xie and Shauman 2003), by reducing the likelihood that a stereotype-eroding critical mass of high-achieving girls will be attained in male-typed programs (RiegleCrumb, Farkas, and Muller 2006; Frank et al. 2008), and by reinforcing the gender labeling of scientific and mathematical activities. ${ }^{42}$ While more universal secondary school requirements may strike some as antidemocratic, this concern must be balanced against the possibility that girls' and boys' seemingly free choices are constrained by taken-for-granted assumptions about what they will like and what they are good at and by the social sanctions that they may anticipate should they elect to pursue gender-atypical educational and career paths.

${ }^{41}$ Under communist regimes in some eastern and central European countries, both boys and girls were required to study math and science throughout secondary school. Gerber and Schaefer (2004) report that the growing emphasis on individual choice has been accompanied by a greater intrusion of gender stereotyping into the Russian system. Restrictions on choice at the secondary or tertiary levels are also found in Turkey, Ireland, and Korea, all countries where women are relatively well represented in computer science programs (Charles and Bradley 2006). We do not find strong female representation in engineering in these countries, but women are slightly overrepresented in mathematics and natural science programs in all three.

${ }^{42}$ For some of these reasons, a 1993 U.K. white paper recommended that all students be required to study at least one technical subject until age 16 (Lightbody and Durndell 1998). 
American Journal of Sociology

Enrollment in single-sex secondary schools or classrooms has been suggested as one means of reducing the salience of gender and the frequency of gender performances during the formative adolescent years (Thompson 2003). Although some beneficial psychological and pedagogic effects have been documented (Lee and Marks 1990; Shapka and Keating 2003), any large-scale initiative toward single-sex education would undoubtedly bring a host of unintended consequences (e.g., Datnow, Hubbard, and Conchas 2001). More important, we note that the philosophical rationale for single-sex educational policy initiatives is often based upon those very same gender-essentialist presumptions that have helped give rise to the segregation of scientific and technical fields in the first place (Hoff Sommers 2000; Gurian 2002). Intentional sex segregation of public schools or high school mathematics classes strikes us as an unrealistic policy option.

\section{Trajectories of Development}

Our results also raise questions regarding the future of sex segregation in less-developed and transitional economies. Will rising levels of material affluence and structural modernization be accompanied by convergence on a common advanced-industrial segregation regime? Although this remains an open question, some evidence points to distinct historical trajectories of development. Stinchcombe (1965) has argued that organizational forms are imprinted by the environmental conditions operative during the time of their establishment or expansion. We observe that some degree programs and organizational practices that are now found in the postindustrial West evolved during a historical era when essentialist representations of gender difference were explicitly built into educational policy making. When the above-quoted UNESCO passage was written in 1953, for example, the potential social and economic costs associated with sex segregation seemed to warrant no mention. The resultant policies (e.g., curricular offerings, structural diversification, tracking) facilitated women's entry into higher education while simultaneously encouraging and legitimizing gendered educational pathways in the United States and Europe.

The international norms governing educational policy making have changed since the postwar era. Although gender-essentialist beliefs still deeply permeate popular culture and interpersonal relationships, they are less often explicitly propagated by elite educational practitioners and scholars, and the practice of creating male- or female-targeted educational programs is decreasingly legitimate in international educational policy circles (e.g., within the World Bank and UNESCO) ${ }^{43}$ These world-cul-

${ }^{43}$ The delegitimation of references to innate gender difference by educational officials 
tural shifts may be more directly "imprinted" upon educational structures that expanded during historical periods when overt gender stereotyping was less normatively acceptable.

Variations in local circumstances are also important. In developing countries, educational and economic policy makers have invested much effort into expanding the supply of engineering and scientific labor because these fields are today seen as engines of national development and because of historically large outflows of qualified technical personnel to the West (National Academy of Engineering 2004; National Academy of Sciences 2007). Such labor constraints may discourage the development of programs catering to perceived female aptitudes. In addition, the strong female presence in science and engineering found in some Asian countries is partly attributable to weaker cultural beliefs in the "innateness" of mathematics (Xie and Shauman 2003).

Conversely, convergence on the advanced industrial pattern may occur through growing democratization of educational systems, which has been linked to increasing sex segregation of curricular choice in some former Soviet states (Gerber and Schaefer 2004). Our results suggest, moreover, that growing affluence and postindustrial economic restructuring may be accompanied by increasing sex segregation by field of study in some currently industrializing societies.

These findings point to a need for more cross-national and historical research on how macrocultural beliefs, economic opportunity structures, and educational transformations influence aspirations, curricular affinities, and patterns of sex segregation in more and less economically developed countries. In particular, historical case studies and in-depth qualitative research conducted in countries that vary on key dimensions considered here could help specify the mechanisms underlying relationships that we have identified. More systematic comparative research is also needed on how organizational features of secondary systems influence gender distributions within and across institutions of higher education.

\section{Conclusion}

The second half of the 20th century has been characterized by a broad diffusion of gender-egalitarian ideology and significant declines in the sort of blatant discrimination that historically supported female exclusion from high-status educational institutions. But gender-essentialist beliefs are alive and well, and they appear to gather strength within the self-ex-

can be seen in the public outcry following a suggestion in 2005 by the then-president of Harvard, Lawrence Summers, that women may be less capable than men of highlevel scientific and technical reasoning. 
American Journal of Sociology

pressive cultures that arise under advanced industrialism. Sex segregation by field of study will not erode with economic or cultural modernization, but will persist as long as persons continue to understand themselves, their competencies, and their educational and occupational opportunities in fundamentally gendered terms.

\section{APPENDIX A}

Data, Measures, and Sources

\section{Sex Segregation Data}

Data on male and female graduates' distributions across fields of study are taken from table 3.12 of UNESCO's Statistical Yearbooks (1995, 1997, 1998). They pertain to the latest available year, which ranges from 1993 to 1998 (except for Malaysia, whose data are from 1990). Fields are coded according to the international standard classification of education (ISCED). In order to arrive at an internationally harmonized classification, ISCED fields were collapsed into the following mutually exclusive and exhaustive categories: (1) engineering; (2) math/natural science (including computer science); (3) humanities/social science (education, humanities, art, law, social and behavioral sciences, business, mass communications, home economics, service trades); and (4) health/other (health, architecture, trade, craft, transport, agriculture, other). In some countries, the engineering category includes transport and communications (Bulgaria), trade, craft, and industrial programs (Chile and Latvia), architecture (Israel), or architecture and town planning, trade craft and industrial programs, and some math and computer science (Japan). Australian and Malaysian figures do not include vocational students. Data are aggregated across ISCED tertiary levels 5, 6, and 7, which correspond to two-year vocational colleges, four-year universities, and postgraduate programs, respectively.

\section{Covariates}

1. Economic development.-Natural log of 1990 GDP per capita (United Nations Development Programme 1999).

2. Postindustrialism.-Mean of standardized scores on service-sector size and employee-class size. Data are from the International Labour Organisation's (ILO) online LABORSTA database or (for France, Indonesia, Philippines, Tunisia, and Turkey) the ILO's $(1992,1994)$ Yearbook of Labour Statistics.$^{44}$ No data were available for Jordan, so we substituted the mean values of the service-sector and employee-class variables cal-

${ }^{44}$ The LABORSTA database is located at http://laborsta.ilo.org. 
culated for the developing/transitional subsample. Because of changes in the ILO's classification of industries and employment status during the early 1990s, data are for 1993-95 unless otherwise noted.

(a) Share of the labor force working in service industries.-Workers in industrial categories 6, 7, 8, and 9 ("trade, restaurants, and hotels," "transport and communication," "financing and business services," and "community, social, and personal services") as a percentage of the total labor force, excluding individuals whose industrial location was "not adequately defined." Data were collected outside our 1993-95 target period for Tunisia (1989), Ireland (1991), Belgium, Greece, Indonesia, and Italy (1992), Iran and Latvia (1996), South Africa (2000), and Macedonia (2002).

(b) Share of the labor force working as employees.-Workers in status category 1 ("employee") as a percentage of the total labor force, excluding individuals "not classified by status." Data were collected outside our 1993-95 target period for Tunisia (1989), Indonesia (1992), Chile, Iran, and Norway (1996), Macedonia (1997), Cyprus (1999), South Africa (2001), and Bulgaria (2003).

3. Labor force \%female, 1990.-Source: United Nations 1999, table 3.6; values for Czech Republic, Jordan, Latvia, and Russia are taken from table 3.8.

4. Professions \%female, 1990.-Source: United Nations 1999, table 3.6; values for Czech Republic, Jordan, Latvia, and Russia are taken from the ILO's LABORSTA database and cover the years 1979 (Jordan), 1991 (Czech Republic), and 2000 (Latvia and Russia).

5. Tertiary system size.-Natural logarithm of total enrolled students. Survey years are matched as closely as possible to those used to calculate the sex segregation values. Source: UNESCO 1992, 1995, 1996a, 1997, 1998, table 3.11.

6. Educational diversification.-Students enrolled in level-5 programs ("programs leading to an award not equivalent to a first university degree") as a percentage of all higher education students. Survey years are matched as closely as possible to those used to calculate the sex segregation values. Source: UNESCO 1992, 1995, 1996a, 1997, 1998, table 3.11.

7. Graduates \%female.-Source: UNESCO 1995, 1997, 1998. Survey years correspond to those used to calculate the sex segregation values.

8. Girls' affinity for math.-Measured as the difference (girls - boys) between the percentage of girls and the percentage of boys who claim to "like mathematics" plus the difference between the percentage of girls and the percentage of boys who claim to "like mathematics a lot." Girls and boys are surveyed at the eighth-grade level. Source: TIMSS 1995 survey where available, else 1999.

9. Girls' math achievement.-Difference between national average mathematics achievement scores of eighth-grade girls and eighth-grade boys (girls - boys). Source: TIMSS 1995, 1999. 


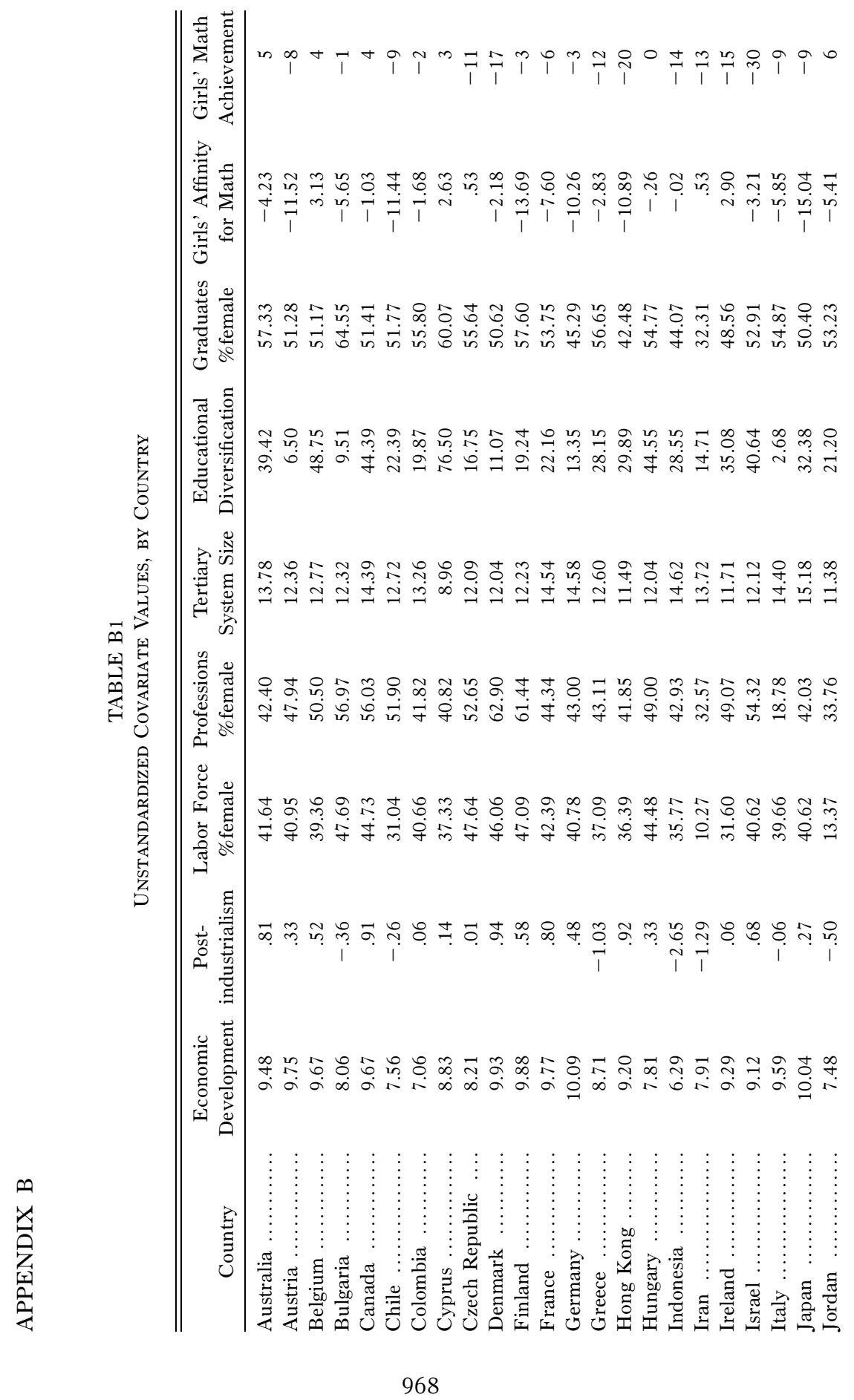




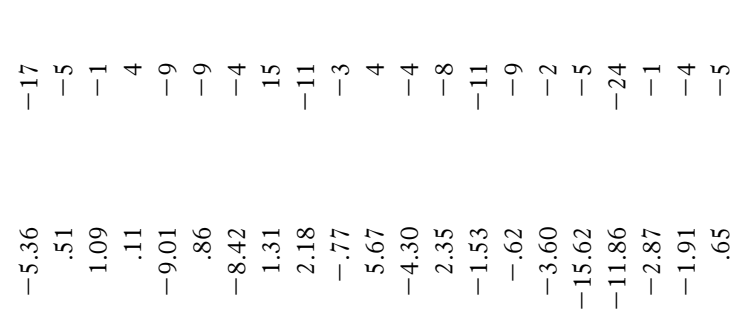

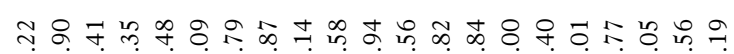

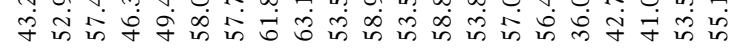

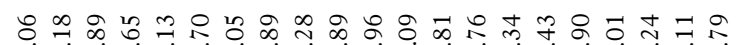

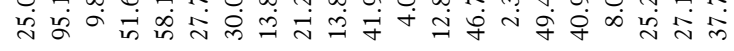

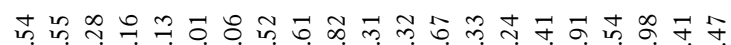

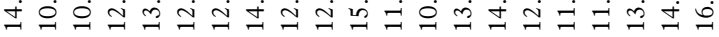

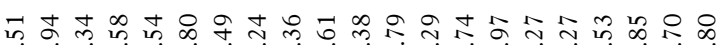

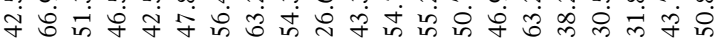

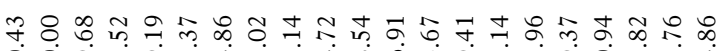

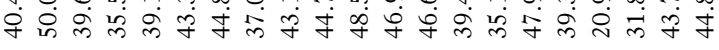

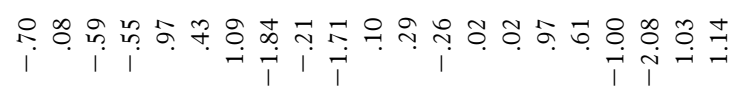

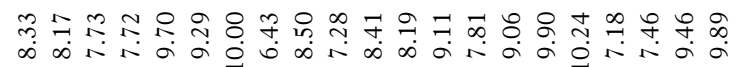

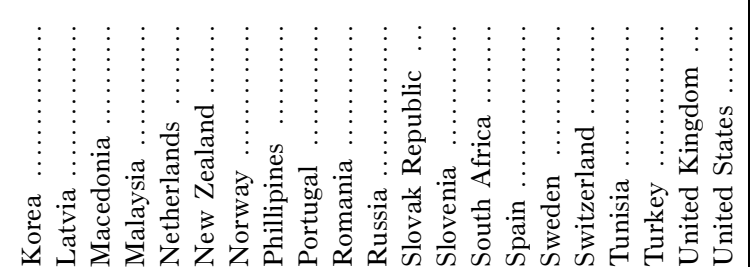

969 
American Journal of Sociology

\section{REFERENCES}

$\rightarrow$ Ayalon, Hanna. 2003. "Women and Men Go to University: Mathematical Background and Gender Differences in Choice of Field of Higher Education." Sex Roles 48: 277-90.

Bae, Yupin, Susan Choy, Claire Geddes, Jennifer Sable, and Thomas Snyder. 2000. Trends in Educational Equity for Girls and Women. Report no. NCES 2000-030. Washington, D.C.: National Center for Educational Statistics.

Baker, David P., and Gerald K. Letendre. 2005. National Differences, Global Similarities: World Culture and the Future of Schooling. Stanford, Calif.: Stanford University Press.

$\rightarrow$ Baker, David P., and Deborah Perkins Jones. 1993. "Creating Gender Equality: Crossnational Gender Stratification and Mathematical Performance." Sociology of Education 66:91-103.

$\rightarrow$ Banaji, Mahzarin R., and Curtis D. Hardin. 1996. "Automatic Stereotyping." Psychological Science 7:136-41.

$\rightarrow$ Barinaga, Marcia. 1994. "Surprises across the Cultural Divide." Science 263:1468-72.

Baron-Cohen, Simon. 2003. The Essential Difference: The Truth about the Male and Female Brain. New York: Basic Books.

Beck, Ulrich, and Elisabeth Beck-Gernsheim. 2001. Individualization: Institutionalized Individualism and Its Social and Political Consequences. Newbury Park, Calif.: Sage.

Bell, Daniel. 1976. The Coming of Post-industrial Society. New York: Basic Books.

Bem, Sandra Lipsitz. 1993. The Lenses of Gender: Transforming the Debate on Sexual Inequality. New Haven, Conn.: Yale University Press.

$\rightarrow$ Berkovitch, Nitza, and Karen Bradley. 1999. "The Globalization of Women's Status: Consensus/Dissensus in the World Polity." Sociological Perspectives 42:481-98.

Bielby, William T., and James N. Baron. 1984. "A Woman's Place Is with Other Women: Sex Segregation within Organizations." Pp. 27-55 in Sex Segregation in the Workplace: Trends, Explanations, and Remedies, edited by Barbara Reskin. Washington, D.C.: National Academies Press.

Bix, Amy Sue. 2006. "From 'Engineeresses' to 'Girl Engineers' to 'Good Engineers': A History of Women's U.S. Engineering Education.” Pp. 46-65 in Removing Barriers: Women in Academic Science, Technology, Engineering and Mathematics, edited by Jill M. Bystydzienski and Sharon R. Bird. Bloomington: Indiana University Press.

$\rightarrow$ Bradley, Karen. 2000. "The Incorporation of Women into Higher Education: Paradoxical Outcomes?" Sociology of Education 73:1-18.

$\rightarrow$ Bradley, Karen, and Maria Charles. 2004. "Uneven Inroads: Understanding Women's Status in Higher Education." Research in Sociology of Education 14:247-74.

$\rightarrow$ Bradley, Karen, and Diana Khor. 1993. "Toward an Integration of Theory and Research on the Status of Women." Gender and Society 7:347-78.

Bradley, Karen, and Francisco O. Ramirez. 1996. "World Polity and Gender Parity: Women's Share of Higher Education, 1965-85." Research in Sociology of Education and Socialization 11:63-91.

$\rightarrow$ Buchmann, Claudia, and Ben Dalton. 2002. "Interpersonal Influences and Educational Aspirations in 12 Countries: The Importance of Institutional Context." Sociology of Education 75:99-122.

$\rightarrow$ Buchmann, Claudia, and Thomas A. DiPrete. 2006. "The Growing Female Advantage in College Completion: The Role of Family Background and Academic Achievement." American Sociological Review 71:515-41.

Bystydzienski, Jill M., and Sharon R. Bird. 2006. "Introduction." Pp. 1-19 in Removing Barriers: Women in Academic Science, Technology, Engineering and Mathematics, 
edited by Jill M. Bystydzienski and Sharon R. Bird. Bloomington: Indiana University Press.

$\rightarrow$ Catsambis, Sophia. 1994. "The Path to Math: Gender and Racial-Ethnic Differences in Mathematics Preparation from Middle School to High School." Sociology of Education 67:199-215.

$\rightarrow$ Charles, Maria. 1992. "Cross-national Variation in Occupational Sex Segregation." American Sociological Review 57:483-502.

$\rightarrow$. 2005. "National Skill Regimes, Postindustrialism, and Sex Segregation." Social Politics 12:289-316.

$\rightarrow$ Charles, Maria, and Karen Bradley. 2002. "Equal but Separate: A Cross-national Study of Sex Segregation in Higher Education.” American Sociological Review 67:573-99.

_ 2006. "A Matter of Degrees: Female Underrepresentation in Computer Science Programs Cross-nationally.” Pp. 183-203 in Women and Information Technology: Research on the Reasons for Underrepresentation, edited by Joanne McGrath Cohoon and Bill Aspray. Cambridge, Mass.: MIT Press.

$\rightarrow$ Charles, Maria, Marlis Buchmann, Susan Halebsky, Jeanne Powers, and Marisa M. Smith. 2001. "The Context of Women's Market Careers: A Cross-national Study." Work and Occupations 28:371-96.

$\rightarrow$ Charles, Maria, and David B. Grusky. 1995. "Models for Describing the Underlying Structure of Sex Segregation." American Journal of Sociology 100:931-71.

- 2004. Occupational Ghettos: The Worldwide Segregation of Women and Men. Stanford, Calif.: Stanford University Press.

Chodorow, Nancy. 1978. The Reproduction of Mothering: Psychoanalysis and the Sociology of Gender. Berkeley: University of California Press.

Cockburn, Cynthia. 1985. Machinery of Dominance: Women, Men and Technical Know-how. London: Pluto Press.

$\rightarrow$ Collis, Betty A., and Richard L. Williams. 1987. "Cross-cultural Comparison of Gender Differences in Adolescents' Attitudes toward Computers and Selected School Subjects." Journal of Educational Research 81:17-27.

$\rightarrow$ Correll, Shelley J. 2001. "Gender and the Career Choice Process: The Role of Biased Self-Assessments.” American Journal of Sociology 106:1691-1730.

$\rightarrow$ - 2004. "Constraints into Preferences: Gender, Status, and Emerging Career Aspirations." American Sociological Review 69:93-113.

$\rightarrow$ Correll, Shelley J., Stephen Benard, and In Paik. 2007. "Getting a Job: Is There a Motherhood Penalty?" American Journal of Sociology 112:1297-1338.

$\rightarrow$ Datnow, Amanda, Lea Hubbard, and Gilberto Q. Conchas. 2001. "How Context Mediates Policy: The Implementation of Single Gender Public Schooling in California." Teachers College Record 103:184-206.

$\rightarrow$ Della Fave, L. R. 1980. "The Meek Shall Not Inherit the Earth: Self-Evaluation and the Legitimacy of Social Stratification.” American Sociological Review 45:955-71.

$\rightarrow$ Downey, Gary Lee, and Juan C. Lucena. 2005. "National Identities in Multinational Worlds: Engineers and 'Engineering Cultures." International Journal on Continuing Engineering Education and Lifelong Learning 15:252-60.

Drori, Gili S., John W. Meyer, Francisco O. Ramirez, and Evan Schofer. 2003. Science in the Modern World Polity. Stanford, Calif.: Stanford University Press.

$\rightarrow$ Duncan, Otis D., and Beverly Duncan. 1955. "A Methodological Analysis of Segregation Indexes." American Sociological Review 20:210-17.

Eagly, Alice H., Wendy Wood, and Amanda B. Diekman. 2000. "Social Role Theory of Sex Differences and Similarities: A Current Appraisal." Pp. 123-74 in The Developmental Psychology of Gender, edited by Thomas Eckes and Hanns M. Trautner. Mahwah, N.J.: Lawrence Erlbaum.

Eccles, Jacquelynne S. 2007. "Where Are All the Women? Gender Differences in Participation in Physical Science and Engineering." Pp. 199-2 10 in Why Aren't More 
American Journal of Sociology

Women in Science? Top Researchers Debate the Evidence, edited by Stephen J. Ceci and Wendy M. Williams. Washington, D.C.: American Psychological Association.

$\rightarrow$ Elgqvist-Saltzman, Inga. 1988. "Educational Reforms: Women's Life Patterns; A Swedish Case Study." Higher Education 17:491-504.

$\rightarrow$ England, Paula. 2005. "Emerging Theories of Care Work." Annual Review of Sociology $31: 381-99$

. 2006. "Toward Gender Equality: Progress and Bottlenecks." Pp. 245-64 in The Declining Significance of Gender? edited by Francine D. Blau, Mary C. Brinton, and David B. Grusky. New York: Russell Sage Foundation.

England, Paula, Paul Allison, Su Li, et al. 2007. "Why Are Some Academic Fields Tipping toward Female? The Sex Composition of U.S. Fields of Doctoral Degree Receipt, 1971-2002." Sociology of Education 80:23-42.

England, Paula, and Su Li. 2006. "Desegregation Stalled: The Changing Gender Composition of College Majors, 1971-2002." Gender and Society 20:657-77.

$\rightarrow$ Entwisle, Doris R., and Ellen Greenberger. 1972. "Adolescents' View of Women's Work Role." American Journal of Orthopsychiatry 42:648-56.

Estévez-Abe, Margarita, Torben Iversen, and David Soskice. 2003. "Social Protection and the Formation of Skills: A Reinterpretation of the Welfare State." Pp. 145-83 in Varieties of Capitalism: The Institutional Foundations of Comparative Advantage, edited by Peter A. Hall and David Soskice. New York: Oxford University Press.

European Commission Directorate-General for Research. 2006. She Figures 2006: Women and Science Statistics and Indicators. Luxembourg: Office for Official Publications of the European Communities.

$\rightarrow$ Faulkner, Wendy. 2000. "Dualisms, Hierarchies and Gender in Engineering." Social Studies of Science 30:759-92.

$\rightarrow \longrightarrow$. 2007. "Nuts and Bolts and People': Gender-Troubled Engineering Identities." Social Studies of Science 37:331-56.

Fenstermaker, Sarah, and Candace West, eds. 2002. Doing Gender, Doing Difference: Inequality, Power, and Institutional Change. New York: Routledge.

Fjelde, H. V. 1991. "Public-Private Tendencies within Higher Education in Norway from a Women's Perspective." Pp. 117-30 in Women's Higher Education in Comparative Perspective, G. P. Kelly and S. Slaughter. Dordrecht: Kluwer Academic Publishers.

$\rightarrow$ Fox, Mary Frank. 2001. "Women, Science, and Academia: Graduate Education and Careers." Gender and Society 15:654-66.

$\rightarrow$ Frank, David John, and John Meyer. 2002. "The Profusion of Individual Roles and Identities in the Postwar Period." Sociological Theory 20:86-105.

- 2007. "Worldwide Expansion and Change in the University." Pp. 19-42 in Towards a Multiversity? Universities between Global Trends and National Traditions, edited by Georg Krücken, Anna Kosmützky, and Marc Torka. Bielefeld: Transcript-Verlag.

$\rightarrow$ Frank, Kenneth A., Chandra Muller, Kathryn S. Schiller, Catherine Riegle-Crumb, Anna Strassmann Mueller, Robert Crosnoe, and Jennifer Pearson. 2008. "The Social Dynamics of Mathematics Coursetaking in High School." American Journal of Sociology 113 (6): 1645-96.

$\rightarrow$ Gaskell, Jane. 1985. "Course Enrollments in the High School: The Perspective of Working-Class Females." Sociology of Education 58:48-59.

Gecas, Viktor. 1991. "The Self-Concept as a Basis for a Theory of Motivation." Pp. 171-87 in The Self-Society Dynamic: Cognition, Emotion, and Action, edited by J. A. Howard and P. L. Callero. New York: Cambridge University Press.

$\rightarrow$ Gerber, Theodore P., and David R. Schaefer. 2004. "Horizontal Stratification of Higher Education in Russia: Trends, Gender Differences, and Labor Market Outcomes." Sociology of Education 77:32-59.

Gharibyan, Hasmik. 2006. "Work in Progress-Women in Computer Science: Why 
There Is No Problem in One Former Soviet Republic." Paper presented at the ASEE/ IEE Frontiers in Education Conference, San Diego, Calif., October 28-31.

Giddens, Anthony. 1990. The Consequences of Modernity. Cambridge, Mass.: Polity.

Glick, Peter, and Susan T. Fiske. 1999. "Gender, Power Dynamics, and Social Interaction.” Pp. 365-98 in Revisioning Gender, edited by Myra Marx Ferree, Judith Lorber, and Beth B. Hess. Thousand Oaks, Calif.: Sage.

$\rightarrow$ Goldin, Claudia, Lawrence F. Katz, and Ilyana Kuziemko. 2006. "The Homecoming of American College Women: The Reversal of the College Gender Gap." Journal of Economic Perspectives 20:133-56.

Goode, William J. 1963. World Revolution and Family Patterns. New York: Free Press.

Gurian, Michael. 2002. Boys and Girls Learn Differently! A Guide for Teachers and Parents. San Francisco: Jossey-Bass.

$\rightarrow$ Hakim, Catherine. 1991. "Grateful Slaves and Self-Made Women: Fact and Fantasy in Women's Work Orientations.” European Sociological Review 7:101-21.

Hanson, Sandra L. 1996. Lost Talent: Women in the Sciences. Philadelphia: Temple University Press.

$\rightarrow$ Hanson, Sandra L., Maryellen Schaub, and David Baker. 1996. "Gender Stratification in the Science Pipeline: A Comparative Analysis of Seven Countries." Gender and Society 10:271-90.

Hoff Sommers, Christina. 2000. The War against Boys. New York: Simon \& Schuster.

ILO (International Labour Organization). 1992. Yearbook of Labour Statistics. Geneva: ILO.

. 1994. Yearbook of Labour Statistics. Geneva: ILO.

Inglehart, Ronald. 1997. Modernization and Postmodernization: Cultural, Economic, and Political Change in 43 Societies. Princeton, N.J.: Princeton University Press.

Inglehart, Ronald, and Pippa Norris. 2003. Rising Tide: Gender Equality and Cultural Change around the World. New York: Cambridge University Press.

Inglehart, Ronald, and Christian Welzel. 2005. Modernization, Cultural Change and Democracy: The Human Development Sequence. Cambridge: Cambridge University Press.

Jackson, Robert Max. 1998. Destined for Equality: The Inevitable Rise of Women's Status. Cambridge, Mass.: Harvard University Press.

. 2006. "Opposing Forces: How, Why, and When Will Gender Inequality Disappear?" Pp. 215-44 in The Declining Significance of Gender? edited by Francine D. Blau, Mary C. Brinton, and David B. Grusky. New York: Russell Sage Foundation.

$\rightarrow$ Jacobs, Jerry. 2003. "Detours on the Road to Equality: Women, Work and Higher Education." Contexts 2:32-41.

Kanter, Rosabeth Moss. 1977. Men and Women of the Corporation. New York: Basic Books.

Kerr, Clark. 1991. The Great Transformation in Higher Education, 1960-1980. New York: SUNY Press.

$\rightarrow$ Lee, James Daniel. 2002. "More than Ability: Gender and Personal Relationships Influence Science and Technology Involvement." Sociology of Education 75:349-73.

$\rightarrow$ Lee, Valerie E., and Helen M. Marks. 1990. "The Effects of Single-Sex Secondary Schools on Student Achievement and Attitudes." Journal of Educational Psychology 78:578-92.

$\rightarrow$ Light, Jennifer S. 1999. "When Computers Were Women." Technology and Culture 40: 455-83.

Lightbody, Pauline, and Alan Durndell. 1998. "Using Stereotypes to Dispel Negative Perceptions of Careers in Science and Technology." Pp. 37-58 in Gender and Choice in Education and Occupation, edited by John Radford. London: Routledge.

Lopez-Claros, Augusto, and Saadia Zahidi. 2005. Women's Empowerment: Measuring the Global Gender Gap. Geneva: World Economic Forum. 
American Journal of Sociology

$\rightarrow$ Lueptow, Lloyd B., Lori Garovich-Szabo, and Margaret B. Lueptow. 2001. "Social Change and the Persistence of Sex Typing: 1974-1997." Social Forces 80:1-35.

$\rightarrow$ Mandel, Hadas, and Moshe Semyonov. 2006. "A Welfare State Paradox: State Interventions and Women's Employment Opportunities in 22 Countries." American Journal of Sociology 111:1910-49.

$\rightarrow$ Marini, Margaret Mooney, Pi-Ling Fan, Erica Finley, and Ann M. Beutel. 1996. "Gender and Job Values." Sociology of Education 69:49-65.

Meek, V. Lynn, and Leo Goedegebuure, eds. 1996. The Mockers and the Mocked: Comparative Perspectives on Differentiation, Convergence and Diversity in Higher Education. Paris: IAU Press.

$\rightarrow$ Meyer, John W., and Ronald L. Jepperson. 2000. "The 'Actors' of Modern Society: The Cultural Construction of Social Agency." Sociological Theory 18:100-120.

$\rightarrow$ Meyer, John W., Francisco O. Ramirez, Richard Rubinson, and John Boli-Bennett. 1977. "The World Educational Revolution, 1950-1970." Sociology of Education 50: 242-58.

Milkman, Ruth. 1987. Gender at Work: The Dynamics of Job Segregation by Sex during World War II. Urbana: University of Illinois Press.

National Academy of Engineering. 2004. The Engineer of 2020: Visions of Engineering in the New Century. Washington, D.C.: National Academies Press.

National Academy of Sciences. 2005. Beyond Bias and Barriers: Fulfilling the Potential of Women in Academic Science and Engineering. Executive summary posted at http: //www.nap.edu/catalog/11741.html. Accessed December 31, 2008.

. 2007. Rising above the Gathering Storm: Energizing and Employing America for a Brighter Economic Future. Washington, D.C.: National Academies Press.

National Agency for Higher Education and Statistics Sweden. 1998. Women and Men in Higher Education - from Upper Secondary to Postgraduate Training, 1986/ 87-1995/96. Stockholm: National Agency for Higher Education and Statistics.

NCES (National Center for Educational Statistics). 2003. "A Descriptive Summary of 1999-2000 Bachelor's Degree Recipients One Year Later.” Statistical analysis report no. NCES 2003-165. Washington, D.C.: NCES.

Noel-Levitz. 2007. National Freshman Attitudes Report. Available at http:// www.noellevitz.com/freshman. Accessed December 31, 2008.

$\rightarrow$ Nosek, Brian A., Mahzarin R. Banaji, and Anthony G Greenwald. 2002. "Math = Male, $\mathrm{Me}=$ Female, Therefore Math $\neq$ Me." Journal of Personality and Social Psychology 83:44-59.

NSF (National Science Foundation). 2001. Women, Minorities and Persons with Disabilities in Science and Engineering 2000. Report no. NSF 00-327. Washington, D.C.: NSF.

OECD (Organization for Economic Cooperation and Development). 1986. Girls and Women in Education. Paris: OECD. 2004. Education at a Glance. Paris: OECD.

Oppenheimer, Valerie K. 1970. The Female Labor Force in the United States: Demographic and Economic Factors Governing Its Growth and Changing Composition. Berkeley: Institute for International Studies.

Parsons, Talcott. 1970. "Equality and Inequality in Modern Society, or Social Stratification Revisited." Pp. 14-72 in Social Stratification: Research and Theory for the 1970s, edited by Edward O. Laumann. Indianapolis: Bobbs-Merrill.

Penner, Andrew M. 2008. "Gender Differences in Extreme Mathematical Achievement: An International Perspective on Biological and Social Factors." American Journal of Sociology 114 (suppl.): S138-S170.

$\rightarrow$ Polachek, Solomon William. 1978. "Sex Differences in College Major." Industrial and Labor Relations Review 31:498-508.

$\rightarrow$ Pronin, Emily, Claude M. Steele, and Lee Ross. 2003. "Identity Bifurcation in Response 
Sex Segregation

to Stereotype Threat: Women and Mathematics." Journal of Experimental Social Psychology 40:152-68.

Ramirez, Francisco O. 1987. "Global Changes, World Myths, and the Demise of Cultural Gender: Implications for the United States." Pp. 257-73 in America's Changing Role in the World System, edited by T. Boswell and A. Bergesen. New York: Praeger.

$\rightarrow$ Ramirez, Francisco O., Yasemin Soysal, and Suzanne Shanahan. 1997. "The Changing Logic of Political Citizenship: Cross-national Acquisition of Women's Suffrage Rights, 1890 to 1990." American Sociological Review 62:735-45.

Ramirez, Francisco O., and Christine Min Wotipka. 2001. "Slowly but Surely? The Global Expansion of Women's Participation in Science and Engineering Fields of Study, 1972-92." Sociology of Education 74:231-51.

Rawlings, Craig M. 2007. "Higher Education as a Prism: The Role of Organizational Structures in the Gender Segregation and Stratification of American Undergraduates, 1970-1995.” Working paper. University of California, Santa Barbara, Department of Sociology.

Ridgeway, Cecilia L. 2006. "Gender as an Organizing Force in Social Relations: Implications for the Future of Inequality.” Pp. 265-87 in The Declining Significance of Gender? edited by Francine D. Blau, Mary C. Brinton, and David B. Grusky. New York: Russell Sage Foundation.

$\rightarrow$ Ridgeway, Cecilia L., and Shelley J. Correll. 2004. "Unpacking the Gender System: A Theoretical Perspective on Gender Beliefs and Social Relations." Gender and Society 18:510-31.

$\rightarrow$ Riegle-Crumb, Catherine, George Farkas, and Chandra Muller. 2006. "The Role of Gender and Friendship in Advanced Course Taking." Sociology of Education 79: 206-28.

$\rightarrow$ Roksa, Josipa. 2005. "Double Disadvantage or Blessing in Disguise? Understanding the Relationship between College Major and Employment Sector." Sociology of Education 78:207-32.

Rossiter, Margaret W. 1997. "The Men Move In: Home Economics, 1950-1970.” Pp. 96-117 in Rethinking Home Economics: Women and the History of a Profession, edited by Sarah Stage and Virginia B. Vincenti. Ithaca, N.Y.: Cornell University Press.

Rudas, Tamás. 1998. Odds Ratios in the Analysis of Contingency Tables. Newbury Park, Calif.: Sage.

$\rightarrow$ Schofer, Evan, and John W. Meyer. 2005. "The Worldwide Expansion of Higher Education in the Twentieth Century." American Sociological Review 70:898-920.

$\rightarrow$ Schultz, Theodore. 1961. "Investment in Human Capital." American Economic Review 51:1-17.

Schwartz, Barry. 2004. The Paradox of Choice: Why More Is Less. New York: Harper Collins.

Seymour, Elaine, and Nancy Hewitt. 1997. Talking about Leaving: Why Undergraduates Leave the Sciences. Boulder, Colo.: Westview Press.

$\rightarrow$ Shapka, Jennifer D., and Daniel P. Keating. 2003. "Effects of a Girls-Only Curriculum during Adolescence: Performance, Persistence, and Engagement in Mathematics and Science." American Education Research Journal 40:929-60.

Shavit, Yossi, Richard Arum, and Adam Gamoran, eds. 2007. Stratification in Higher Education: A Comparative Study. Stanford, Calif.: Stanford University Press.

Sirowy, L., and Aaron Benavot. 1986. "Higher Education in an Era of Equality: A Cross-national Study of Institutional Differentiation on the Tertiary Level." Research in Sociology of Education and Socialization 6:1-44.

Spitaleri, Rosa Maria. 1996. "Women's Know-how and Authority: Italian Women and Mathematics." Pp. 205-13 in Towards Gender Equity in Mathematics Education, edited by Gila Hanna. Boston: Kluwer Academic Publishing. 
American Journal of Sociology

Stenstrom, Marja-Leena. 1993. "Gender and Equality in Commercial Education in Finland." International Journal of Vocational Education and Training 1:15-23.

Stinchcombe, Arthur L. 1965. "Social Structure and Organizations." Pp. 142-93 in Handbook of Organizations, edited by James G. March. Chicago: Rand-McNally.

Teichler, Ulrich. 1996. "Diversity in Higher Education in Germany: The Two-Type Structure." Pp. 117-37 in The Mockers and the Mocked: Comparative Perspectives on Differentiation, Convergence and Diversity in Higher Education, edited by V. Lynn Meek and Leo Goedegebuure. Paris: IAU Press.

$\rightarrow$ Thompson, Jennifer S. 2003. "The Effect of Single-Sex Secondary Schooling on Women's Choice of College Major." Sociological Perspectives 46:257-78.

UNDP (United Nations Development Programme). 1999. Human Development Report. CD-ROM. New York: UNDP.

UNESCO (United Nations Educational, Scientific, and Cultural Organization). 1953. Women and Education. Paris: UNESCO.

1992. Statistical Yearbook. Paris: UNESCO.

1995. Statistical Yearbook. Paris: UNESCO.

1996a. Statistical Yearbook. Paris: UNESCO.

1996b. World Science Report 1996. Paris: UNESCO.

1997. Statistical Yearbook. Paris: UNESCO.

1998. Statistical Yearbook. Paris: UNESCO.

United Nations. 1999. Women's Indicators and Statistics Database (WISTAT). New York: United Nations.

$\rightarrow$ van der Lippe, Tanja, and Liset van Dijk. 2002. "Comparative Research on Women's Employment." Annual Review of Sociology 28:221-41.

$\rightarrow$ Van Langen, Annemarie, and Hetty Dekkers. 2005. "Cross-national Differences in Participating in Tertiary Science, Technology, Engineering, and Mathematics Education." Comparative Education 41:329-50.

Williams, John E., and Deborah L. Best. 1990. Measuring Sex Stereotypes: A Multination Study. Newbury Park, Calif.: Sage.

$\rightarrow$ Wiseman, Alexander W. 2008. "A Culture of (In)Equality? A Cross-national Study of Gender Parity and Gender Segregation in National School Systems." Research in Comparative and International Education 3:179-201.

$\rightarrow$ Xie, Yu. 1992. "The Log-Multiplicative Layer Effect Model for Comparing Mobility Tables." American Sociological Review 57:380-95.

$\mathrm{Xie}, \mathrm{Yu}$, and Kimberlee A. Shauman. 2003. Women in Science: Career Processes and Outcomes. Cambridge, Mass.: Harvard University Press. 